\title{
Electrospray Production and Collisional Dissociation of Lanthanide/Methylsulfonyl Anion Complexes: Sulfur Dioxide Anion as a Ligand
}

\author{
Yu Gong ${ }^{1}$, Maria C. Michelini ${ }^{2^{*}}$ and John K. Gibson ${ }^{1^{*}}$ \\ ${ }^{1}$ Chemical Sciences Division, Lawrence Berkeley National Laboratory, Berkeley, CA 94720, USA \\ ${ }^{2}$ Dipartimento di Chimica, Università della Calabria, 87030 Arcavacata di Rende, Italy
}

*Corresponding authors: mc.michelini@unical.it; jkgibson@lbl.gov (submitting author) 


\begin{abstract}
Gas-phase lanthanide- $\mathrm{SO}_{2}$ complexes, $\mathrm{Ln}\left(\mathrm{CH}_{3} \mathrm{SO}_{2}\right)_{3}\left(\mathrm{SO}_{2}\right)^{-}$, were produced by collision induced dissociation (CID) of $\mathrm{Ln}\left(\mathrm{CH}_{3} \mathrm{SO}_{2}\right)_{4}{ }^{-}$precursors prepared by electrospray ionization. For all lanthanides except $\mathrm{Eu}, \mathrm{CID}$ of $\mathrm{Ln}\left(\mathrm{CH}_{3} \mathrm{SO}_{2}\right)_{4}{ }^{-}$resulted in $\mathrm{CH}_{3}$ loss to form $\mathrm{Ln}\left(\mathrm{CH}_{3} \mathrm{SO}_{2}\right)_{3}\left(\mathrm{SO}_{2}\right)^{-}$, which spontaneously react with $\mathrm{O}_{2}$ to form $\mathrm{Ln}\left(\mathrm{CH}_{3} \mathrm{SO}_{2}\right)_{3}\left(\mathrm{O}_{2}\right)^{-}$. CID of $\mathrm{Eu}\left(\mathrm{CH}_{3} \mathrm{SO}_{2}\right)_{4}{ }^{-}$produced only $\mathrm{Eu}\left(\mathrm{CH}_{3} \mathrm{SO}_{2}\right)_{3}{ }^{-}$, with reduction from $\mathrm{Eu}(\mathrm{III})$ to $\mathrm{Eu}(\mathrm{II})$. For $\mathrm{Ln}=\mathrm{Yb}$ and $\mathrm{Sm}$, the $\mathrm{Ln}\left(\mathrm{CH}_{3} \mathrm{SO}_{2}\right)_{4}{ }^{-}$underwent neutral ligand loss to form $\mathrm{Ln}\left(\mathrm{CH}_{3} \mathrm{SO}_{2}\right)_{3}{ }^{-}$, which reacted with $\mathrm{O}_{2}$ to yield $\mathrm{Ln}\left(\mathrm{CH}_{3} \mathrm{SO}_{2}\right)_{3}\left(\mathrm{O}_{2}\right)^{-}$, recovering the $\mathrm{Ln}(\mathrm{III})$ oxidation state. The CID results parallel condensed phase $\mathrm{Ln}^{3+} / \mathrm{Ln}^{2+}$ redox chemistry. Density functional theory (DFT) calculations on $\mathrm{Ln}\left(\mathrm{CH}_{3} \mathrm{SO}_{2}\right)_{3}\left(\mathrm{SO}_{2}\right)^{-}$for $\mathrm{Ln}=\mathrm{La}, \mathrm{Yb}$ and $\mathrm{Lu}$ reveal that $\mathrm{SO}_{2}$ acts as a bidentate oxygen bound ligand for doublet ground state $\mathrm{La}\left(\mathrm{CH}_{3} \mathrm{SO}_{2}\right)_{3}\left(\mathrm{SO}_{2}\right)^{-}$and $\mathrm{Lu}\left(\mathrm{CH}_{3} \mathrm{SO}_{2}\right)_{3}\left(\mathrm{SO}_{2}\right)^{-}$, while the ground state for $\mathrm{Yb}\left(\mathrm{CH}_{3} \mathrm{SO}_{2}\right)_{3}\left(\mathrm{SO}_{2}\right)^{-}$is an open-shell singlet with a monodentate $\mathrm{SO}_{2}$ ligand. Loss of $\mathrm{CH}_{3}$ is computed to be much more favorable than neutral ligand loss for $\mathrm{La}\left(\mathrm{CH}_{3} \mathrm{SO}_{2}\right)_{4}{ }^{-}$and $\mathrm{Lu}\left(\mathrm{CH}_{3} \mathrm{SO}_{2}\right)_{4}{ }^{-}$, whereas both channels are comparable in energy for $\mathrm{Yb}\left(\mathrm{CH}_{3} \mathrm{SO}_{2}\right)_{4}{ }^{-}$, in accord with the experiments. DFT results for fragmentation of $\mathrm{Cu}\left(\mathrm{CH}_{3} \mathrm{SO}_{2}\right)_{2}{ }^{-}$reveal that formation of the organometallic complex, $\mathrm{Cu}\left(\mathrm{CH}_{3} \mathrm{SO}_{2}\right)\left(\mathrm{CH}_{3}\right)^{-}$, is energetically most favorable, in agreement with contrasting fragmentation pathways of copper and lanthanide complexes.
\end{abstract}

Keywords: collision induced dissociation; lanthanide complexes; methane sulfinate; sulfur dioxide anion; density functional theory; divalent lanthanides 


\section{Introduction}

The coordination chemistry of $\mathrm{SO}_{2}$ has been well developed in recent years due to interest in weakly coordinated complexes, ${ }^{1}$ as well as in materials for $\mathrm{SO}_{2}$ sensors, which require reversible binding of $\mathrm{SO}_{2}{ }^{2,3}$ Among the coordination complexes whose structures and properties have been well defined, main group elements and electron rich transition metals have been the

primary focus, ${ }^{1,4,5}$ while lanthanides have received less attention. Reactions of lanthanides with $\mathrm{AsF}_{5}$ in liquid $\mathrm{SO}_{2}$ results in the formation of polymeric lanthanide- $\mathrm{SO}_{2}$ adducts. ${ }^{6}$ Discrete molecular $\mathrm{SO}_{2}$ complexes containing lanthanides were unknown until the recent report of the synthesis of several cone-type lanthanide complexes, in which both oxygen atoms of each of the $\mathrm{SO}_{2}$ moieties are bound to a lanthanide metal center protected by a bulky ligand. ${ }^{7}$

It is possible to form unique coordination complexes in the gas phase by using appropriate precursor ligands that can undergo fragmentation upon low-energy collision induced dissociation (CID). ${ }^{8,9}$ Recently, we demonstrated that CID of $\mathrm{UO}_{2}\left(\mathrm{CH}_{3} \mathrm{SO}_{2}\right)_{2}{ }^{-}$resulted in $\mathrm{CH}_{3}$ loss to produce $\mathrm{UO}_{2}\left(\mathrm{CH}_{3} \mathrm{SO}_{2}\right)\left(\mathrm{SO}_{2}\right)^{-}$, in which the $\mathrm{SO}_{2}$ ligand is coordinated to uranium by both oxygen atoms. ${ }^{10}$ This is quite different from the fragmentation patterns observed by O'Hair and co-workers during CID of a copper complex having the $\mathrm{CH}_{3} \mathrm{SO}_{2}$ ligand: loss of $\mathrm{SO}_{2}$ to form an organocopper complex was observed. ${ }^{11}$ Since uranyl is a hard acid, ${ }^{12}$ as are the lanthanides, it should be possible to prepare lanthanide- $\mathrm{SO}_{2}$ adducts using the same fragmentation approach applied to $\mathrm{UO}_{2}\left(\mathrm{CH}_{3} \mathrm{SO}_{2}\right)_{2}{ }^{-}$. In the work reported here, $\mathrm{Ln}\left(\mathrm{CH}_{3} \mathrm{SO}_{2}\right)_{4}{ }^{-}$anions for all the lanthanides (except Pm) were prepared by electrospray ionization (ESI) of solutions containing a lanthanide halide and $\mathrm{CH}_{3} \mathrm{SO}_{2} \mathrm{Na}$. A goal was to discern if CID of these gas-phase complexes reveal essential variations in chemistry across the lanthanide series, particularly differences in the relative stabilities of the trivalent and divalent oxidation states. Density functional theory (DFT) computations were performed on selected complexes to understand the observed chemistry. Fragmentation pathways for complexes of copper with the $\mathrm{CH}_{3} \mathrm{SO}_{2}{ }^{-}$ligand were also computed to illuminate the disparate fragmentation behavior of complexes of the "hard" lanthanides and "soft" late transition metals.

\section{Experimental and Computational Details}

All experiments were performed using an Agilent 6340 quadrupole ion trap mass spectrometer (QIT/MS). ${ }^{13}$ The $\mathrm{Ln}\left(\mathrm{CH}_{3} \mathrm{SO}_{2}\right)_{4}{ }^{-}$anions were produced by ESI of methanol $(<5 \%$ 
water) solutions of $\mathrm{CH}_{3} \mathrm{SO}_{2} \mathrm{Na}$ (Sigma-Aldrich) and $\mathrm{LnX}_{3}(\mathrm{X}=\mathrm{Cl}$ or $\mathrm{Br}, 200 \mu \mathrm{M})$ (Sigma-Aldrich) with about 4:1 molar excess $\mathrm{CH}_{3} \mathrm{SO}_{2} \mathrm{Na}$. The $\mathrm{MS}^{\mathrm{n}}$ capabilities of the QIT/MS allow isolation of ions with a particular m/z, followed by CID in which ions are excited and undergo multiple lowenergy collisions with helium. The reported CID results correspond to an applied voltage of 0.6 V for $40 \mathrm{~ms}$. Experiments employing different CID voltages and/or times resulted in changes in product yields but no discernable changes in fragmentation products; specifically, the distinctive products observed for the $\mathrm{Sm}, \mathrm{Eu}$ and $\mathrm{Yb}$ complexes were not observed for other lanthanides. The consistency of results upon varying the CID conditions indicates that the results are phenomenological, not instrumental, as has been demonstrated in analogous studies by O'Hair and co-workers, ${ }^{8,9,11}$ as well as in previous work performed by our group. ${ }^{10,14-16}$ In the present study the ion intensities were sufficient to perform CID of ions produced by ESI, i.e., $\mathrm{MS}^{2}$, but the fragment ion intensities were insufficient to perform sequential CID, i.e, $\mathrm{MS}^{3}$. The ions isolated inside the trap from the ESI source are at a temperature around $300 \mathrm{~K}^{17}$ In high resolution mode, the instrument has a detection range of $\mathrm{m} / \mathrm{z} 20-2200$ with a mass width (FWHM) of $\mathrm{m} / \mathrm{z} \approx 0.3$. The intensity distribution of ions in the mass spectra was highly dependent on instrumental parameters, particularly the RF voltage applied to the ion trap; the parameters were essentially as employed in previous experiments. ${ }^{10}$ The high-purity nitrogen gas for nebulization and drying in the ion transfer capillary was the boil-off from a liquid nitrogen Dewar. As has been discussed elsewhere, ${ }^{18,19}$ the background $\mathrm{H}_{2} \mathrm{O}$ and $\mathrm{O}_{2}$ pressures in the ion trap are estimated to be on the order of $10^{-6}$ Torr. The helium buffer gas pressure in the trap is constant at $\sim 10^{-4}$ Torr.

Geometry optimizations and frequency calculations were performed using the PBE functional (exchange and correlation) ${ }^{20}$ together with triple zeta basis sets and the zero-order regular approximation (ZORA), as implemented in the ADF2009.01 package. ${ }^{21,22}$ The frozen core approximation was used for the lanthanide atoms (up to $4 \mathrm{~d}$ ), and for $\mathrm{Cu}, \mathrm{S}, \mathrm{O}$ and $\mathrm{C}$ atoms (up to $2 \mathrm{p}$ ). This level of theory is referred to as PBE-ZORA/TZ2P. Single point computations were performed using the M06-L functional ${ }^{23}$ in combination with the small-core StuttgartDresden pseudopotentials (SDD) for the $\mathrm{Ln}$ and $\mathrm{Cu}$ atoms, ${ }^{24}$ and $6-311++\mathrm{G}(2 \mathrm{~d}, \mathrm{p})$ basis sets for the rest of the atoms, using the Gaussian09 Rev B.01 program (M06-L/SDD). The M06-L functional has shown good performance in systems containing transition and heavier metals, according to previous reports in literature. ${ }^{25,26}$ Moreover, we have found good performance in the 
estimation of $\mathrm{LnO}$ and $\mathrm{LnO}^{+}$bond dissociation energies for $\mathrm{Ln}=\mathrm{La}$, $\mathrm{Lu}$ (see Tables $\mathrm{S} 1$ and S2 and a brief discussion regarding the choice of the level of theory in Supporting Information). All reported energies (M06-L/SDD//PBE-ZORA/TZ2P) include the zero point vibrational energy corrections at $0 \mathrm{~K}$. Quantum Theory of Atoms in Molecules (QTAIM) analysis was performed on the studied $\mathrm{Ln}\left(\mathrm{CH}_{3} \mathrm{SO}_{2}\right)_{3}\left(\mathrm{CH}_{3}\right)^{-}$ions and, for comparison, on $\mathrm{Cu}\left(\mathrm{CH}_{3} \mathrm{SO}_{2}\right)\left(\mathrm{CH}_{3}\right)^{-27}$ Wavefunction extended files (wfx) were obtained with Gaussian09 at the M06-L/SDD level and analyzed using the AIMAll package. ${ }^{28}$ The electron density $\left(\rho_{\mathrm{BCP}}\right)$, the Laplacian of electron density $\left(\nabla^{2} \rho_{\mathrm{BCP}}\right)$ and total energy density $\left(\mathrm{H}_{\mathrm{BCP}}\right)$ of the $\mathrm{Ln}-\mathrm{C}$ (and $\mathrm{Cu}-\mathrm{C}$ ) bond critical points are included as Supporting Information (Table S3).

\section{Results and Discussion}

\section{ESI and CID Mass Spectra}

The ESI mass spectra of solutions containing $\mathrm{LnX}_{3}$ and $\mathrm{CH}_{3} \mathrm{SO}_{2} \mathrm{Na}$, shown in Figures 1 and 2, revealed a series of peaks over a wide $\mathrm{m} / \mathrm{z}$ range. In addition to peaks due to $\mathrm{Na}_{\mathrm{x}}\left(\mathrm{CH}_{3} \mathrm{SO}_{2}\right)_{\mathrm{x}+1}{ }^{-}$, which is common in ESI experiments with $\mathrm{CH}_{3} \mathrm{SO}_{2} \mathrm{Na},{ }^{10}$ metal complex peaks such as $\mathrm{Ln}\left(\mathrm{CH}_{3} \mathrm{SO}_{2}\right)_{4}{ }^{-}$and $\mathrm{Ln}\left(\mathrm{CH}_{3} \mathrm{SO}_{2}\right)_{4}\left(\mathrm{CH}_{3} \mathrm{SO}_{2} \mathrm{Na}\right)_{\mathrm{x}}{ }^{-}$dominate the spectra. Since the $\mathrm{CH}_{3} \mathrm{SO}_{2}{ }^{-}$

anion can be oxidized to $\mathrm{CH}_{3} \mathrm{SO}_{3}{ }^{-29}$, weak peaks attributed to species comprising $\mathrm{CH}_{3} \mathrm{SO}_{3}{ }^{-}$were also present in the spectra. The $\mathrm{Ln}\left(\mathrm{CH}_{3} \mathrm{SO}_{2}\right)_{4}{ }^{-}$anions of particular interest were mass selected and subjected to CID. As shown in Figure 3, CID of all the $\mathrm{Ln}\left(\mathrm{CH}_{3} \mathrm{SO}_{2}\right)_{4}{ }^{-}$complexes (except $\mathrm{Ln}$ $=\mathrm{Eu})$ resulted in the appearance of a peak $15 \mathrm{~m} / \mathrm{z}$ lower than $\mathrm{Ln}\left(\mathrm{CH}_{3} \mathrm{SO}_{2}\right)_{4}{ }^{-}$, which corresponds to $\mathrm{CH}_{3}$ loss and the formation of $\mathrm{Ln}\left(\mathrm{CH}_{3} \mathrm{SO}_{2}\right)_{3}\left(\mathrm{SO}_{2}\right)^{-}$. In contrast, loss of a neutral $\mathrm{CH}_{3} \mathrm{SO}_{2}$ ligand to form $\mathrm{Eu}\left(\mathrm{CH}_{3} \mathrm{SO}_{2}\right)_{3}{ }^{-}$was the only fragmentation channel for $\mathrm{Eu}\left(\mathrm{CH}_{3} \mathrm{SO}_{2}\right)_{4}{ }^{-}$; a secondary product, $\mathrm{Eu}\left(\mathrm{CH}_{3} \mathrm{SO}_{2}\right)_{2}\left(\mathrm{SO}_{2}\right)^{-}$, was formed when $\mathrm{Eu}\left(\mathrm{CH}_{3} \mathrm{SO}_{2}\right)_{3}{ }^{-}$underwent $\mathrm{CH}_{3}$ loss upon CID. Products arising from neutral ligand loss were also observed for $\mathrm{Yb}\left(\mathrm{CH}_{3} \mathrm{SO}_{2}\right)_{4}{ }^{-}$and $\mathrm{Sm}\left(\mathrm{CH}_{3} \mathrm{SO}_{2}\right)_{4}{ }^{-}$. While both $\mathrm{Yb}\left(\mathrm{CH}_{3} \mathrm{SO}_{2}\right)_{3}{ }^{-}$and $\mathrm{Yb}\left(\mathrm{CH}_{3} \mathrm{SO}_{2}\right)_{3}\left(\mathrm{SO}_{2}\right)^{-}$are major fragmentation products upon $\mathrm{CID}$ of $\mathrm{Yb}\left(\mathrm{CH}_{3} \mathrm{SO}_{2}\right)_{4}{ }^{-}$, the yield of $\mathrm{Sm}\left(\mathrm{CH}_{3} \mathrm{SO}_{2}\right)_{3}{ }^{-}$is much lower than that of $\mathrm{Sm}\left(\mathrm{CH}_{3} \mathrm{SO}_{2}\right)_{3}\left(\mathrm{SO}_{2}\right)^{-}$. Ligand loss was not detected for other $\mathrm{Ln}\left(\mathrm{CH}_{3} \mathrm{SO}_{2}\right)_{4}{ }^{-}$complexes.

\section{Computed Structures of Selected Complexes}

Lanthanide-dependent CID of $\mathrm{Ln}\left(\mathrm{CH}_{3} \mathrm{SO}_{2}\right)_{4}{ }^{-}$reveals the influence of the metal centers on gas-phase fragmentation chemistry. To get further insights into the fragmentation reactions, DFT calculations were carried out on the structures and dissociation reaction thermodynamics of $\mathrm{Ln}\left(\mathrm{CH}_{3} \mathrm{SO}_{2}\right)_{4}{ }^{-}$for $\mathrm{La}, \mathrm{Yb}$, and $\mathrm{Lu}$. We selected $\mathrm{La}$ and $\mathrm{Lu}$ as representative of the lanthanide ions 
that favor trivalency and have, respectively, the largest and smallest $\mathrm{Ln}^{3+}$ ionic radii, and $\mathrm{Yb}$ as a representative lanthanide with a greater propensity towards divalent chemistry. Comprehensive computations for all of the Ln complexes, were beyond the scope of this effort; the DFT results for these representative cases provide insights into the overall experimental results. For comparison, and specifically to understand the differing chemistries of $\mathrm{Ln}$ and $\mathrm{Cu}$, the same dissociation reactions were analyzed by DFT for $\mathrm{Cu}\left(\mathrm{CH}_{3} \mathrm{SO}_{2}\right)_{2}{ }^{-}$. The optimized geometrical parameters of the initial complexes and dissociation products are shown in Figure 4. More information regarding geometrical parameters and electronic states of the ground-state structures and of some relevant higher-energy lanthanide isomers, as well as copper complexes, are

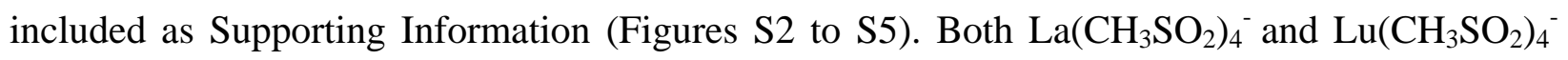
have singlet ground spin states with all the $\mathrm{CH}_{3} \mathrm{SO}_{2}{ }^{-}$ligands having bidentate coordination to the metal center via oxygen atoms. A similar geometry was obtained for the $\mathrm{Yb}\left(\mathrm{CH}_{3} \mathrm{SO}_{2}\right)_{4}{ }^{-}$doublet ground spin state. For the $\mathrm{CH}_{3}$-loss product, isomers very close in energy and differing only in the coordination mode of $\mathrm{SO}_{2}$ (bidentate $v$ s. monodentate) were located. The $\mathrm{La}\left(\mathrm{CH}_{3} \mathrm{SO}_{2}\right)_{3}\left(\mathrm{SO}_{2}\right)^{-}$ doublet spin GS structure is characterized by a bidentate $\mathrm{SO}_{2}$ ligand, whereas the lowest-energy $\mathrm{SO}_{2}$ monodentate isomer is only $17 \mathrm{~kJ} . \mathrm{mol}^{-1}$ higher in energy. The $\mathrm{Lu}\left(\mathrm{CH}_{3} \mathrm{SO}_{2}\right)_{3}\left(\mathrm{SO}_{2}\right)^{-}$doublet spin GS isomer also has a bidentate $\mathrm{SO}_{2}$ ligand and is almost degenerate in energy (within 7 $\left.\mathrm{kJ} . \mathrm{mol}^{-1}\right)$ with the monodentate $\mathrm{SO}_{2}$ isomer. In the case of $\mathrm{Yb}\left(\mathrm{CH}_{3} \mathrm{SO}_{2}\right)_{3}\left(\mathrm{SO}_{2}\right)^{-}$a number of singlet and triplet spin state mono- and bidentate isomers were located within a range of 70 $\mathrm{kJ} \cdot \mathrm{mol}^{-1}$. At the level of theory used here, the lowest-energy structure corresponds to a singlet open-shell structure with a monodentate $\mathrm{SO}_{2}$ ligand. The spin density corresponding to an unpaired electron was found to be delocalized on the $\mathrm{SO}_{2}$ moiety in all the $\mathrm{Ln}\left(\mathrm{CH}_{3} \mathrm{SO}_{2}\right)_{3}\left(\mathrm{SO}_{2}\right)^{-}$ isomers. Moreover, the $\mathrm{S}-\mathrm{O}$ bond distances in the $\mathrm{SO}_{2}$ ligands of $\mathrm{La}\left(\mathrm{CH}_{3} \mathrm{SO}_{2}\right)_{3}\left(\mathrm{SO}_{2}\right)^{-}$and $\mathrm{Lu}\left(\mathrm{CH}_{3} \mathrm{SO}_{2}\right)_{3}\left(\mathrm{SO}_{2}\right)^{-}$(Figures S2 and S4) are ca. $0.02 \AA$ and $0.09 \AA$ longer than those computed for isolated $\mathrm{SO}_{2}^{-}$(1.524 $\AA$ at the present level of theory) and $\mathrm{SO}_{2}(1.459 \AA)$, respectively. Hence, both the $\mathrm{La}\left(\mathrm{CH}_{3} \mathrm{SO}_{2}\right)_{3}\left(\mathrm{SO}_{2}\right)^{-}$and $\mathrm{Lu}\left(\mathrm{CH}_{3} \mathrm{SO}_{2}\right)_{3}\left(\mathrm{SO}_{2}\right)^{-}$complexes are considered as a trivalent lanthanide cation coordinated by three $\mathrm{CH}_{3} \mathrm{SO}_{2}{ }^{-}$ligands and one $\mathrm{SO}_{2}^{-}$ligand, similar to the $\mathrm{UO}_{2}\left(\mathrm{CH}_{3} \mathrm{SO}_{2}\right)\left(\mathrm{SO}_{2}\right)^{-}$complex. ${ }^{10}$ Although the two $\mathrm{S}-\mathrm{O}$ bond lengths of $\mathrm{SO}_{2}$ in $\mathrm{Yb}\left(\mathrm{CH}_{3} \mathrm{SO}_{2}\right)_{3}\left(\mathrm{SO}_{2}\right)^{-}$differ more than those in $\mathrm{La}\left(\mathrm{CH}_{3} \mathrm{SO}_{2}\right)_{3}\left(\mathrm{SO}_{2}\right)^{-}$and $\mathrm{Lu}\left(\mathrm{CH}_{3} \mathrm{SO}_{2}\right)_{3}\left(\mathrm{SO}_{2}\right)^{-}$due to the monodentate character of $\mathrm{SO}_{2}$ in the $\mathrm{Yb}$ complex, it is reasonable to consider the $\mathrm{SO}_{2}$ ligand 
in $\mathrm{Yb}\left(\mathrm{CH}_{3} \mathrm{SO}_{2}\right)_{3}\left(\mathrm{SO}_{2}\right)^{-}$as $\mathrm{SO}_{2}{ }^{-}$based on comparison with the bond lengths of neutral and anionic $\mathrm{SO}_{2}$ and on the spin density distribution.

\section{Computed Fragmentation Energies of Selected Complexes}

To understand the metal-dependence of the fragmentation patterns, computations were carried out for both $\mathrm{CH}_{3}$ loss (reaction 1) and ligand loss (reactions 2 and 3) for $\mathrm{La}\left(\mathrm{CH}_{3} \mathrm{SO}_{2}\right)_{4}{ }^{-}$, $\mathrm{Yb}\left(\mathrm{CH}_{3} \mathrm{SO}_{2}\right)_{4}{ }^{-}$and $\mathrm{Lu}\left(\mathrm{CH}_{3} \mathrm{SO}_{2}\right)_{4}{ }^{-}$. Experimental results from O'Hair and co-workers indicate that $\mathrm{CID}$ of anionic $\mathrm{Cu}$ complexes favor the formation of the organometallic products, in striking contrast to the $\mathrm{Ln}$ homologues; for the $\mathrm{Cu}\left(\mathrm{CH}_{3} \mathrm{CO}_{2}\right)\left(\mathrm{CH}_{3} \mathrm{SO}_{2}\right)^{-}$complex, CID reaction (4) was observed. ${ }^{11}$ Similarly, our experimental results for CID of $\mathrm{Cu}\left(\mathrm{CH}_{3} \mathrm{SO}_{2}\right)_{2}{ }^{-}$revealed the formation of $\mathrm{Cu}\left(\mathrm{CH}_{3} \mathrm{SO}_{2}\right)\left(\mathrm{CH}_{3}\right)^{-}$, in striking contrast to the homologous $\mathrm{Ln}$ complexes. Although the instrumental conditions may be somewhat different between the different experiments, this result demonstrates that the CID conditions employed here are such that the present results can be compared with those from O'Hair and co-workers. To obtain insight into the origin of the contrasting behavior of $\mathrm{Ln}$ and $\mathrm{Cu}$ we have computed possible $\mathrm{CID}$ reactions for $\mathrm{Cu}\left(\mathrm{CH}_{3} \mathrm{SO}_{2}\right)_{2}{ }^{-}$ (Figure S5, Supporting Information).

$$
\begin{aligned}
& \mathrm{Ln}\left(\mathrm{CH}_{3} \mathrm{SO}_{2}\right)_{4}^{-} \rightarrow \mathrm{Ln}\left(\mathrm{CH}_{3} \mathrm{SO}_{2}\right)_{3}\left(\mathrm{SO}_{2}\right)^{-}+\mathrm{CH}_{3} \\
& \mathrm{Ln}\left(\mathrm{CH}_{3} \mathrm{SO}_{2}\right)_{4}^{-} \rightarrow \mathrm{Ln}\left(\mathrm{CH}_{3} \mathrm{SO}_{2}\right)_{3}{ }^{-}+\mathrm{CH}_{3} \mathrm{OSO} \\
& \mathrm{Ln}\left(\mathrm{CH}_{3} \mathrm{SO}_{2}\right)_{4}^{-} \rightarrow \mathrm{Ln}\left(\mathrm{CH}_{3} \mathrm{SO}_{2}\right)_{3}+\mathrm{CH}_{3} \mathrm{SO}_{2}^{-} \\
& \mathrm{Cu}\left(\mathrm{CH}_{3} \mathrm{CO}_{2}\right)\left(\mathrm{CH}_{3} \mathrm{SO}_{2}\right)^{-} \rightarrow \mathrm{Cu}\left(\mathrm{CH}_{3} \mathrm{CO}_{2}\right)\left(\mathrm{CH}_{3}\right)^{-}+\mathrm{SO}_{2}
\end{aligned}
$$

As reported in Table 1, loss of $\mathrm{CH}_{3}$ is always less endothermic than both neutral and anionic $\mathrm{CH}_{3} \mathrm{SO}_{2}$ ligand loss. Our computations indicate that the neutral methoxysulfinyl cis$\mathrm{CH}_{3} \mathrm{OSO}$ radical is $13 \mathrm{~kJ} \mathrm{~mol}^{-1}$ more stable than the methylsulfonyl $\mathrm{CH}_{3} \mathrm{SO}_{2}$ isomer, which is in agreement with previous DFT (B3LYP/aug-cc-pVTZ, ${ }^{30}$ B3P86/aug-cc-pVTZ, ${ }^{30}$ B3LYP/6$\left.311++\mathrm{G}(\mathrm{d}, \mathrm{p})^{31}\right) \quad$ and ab-initio $\quad\left(\mathrm{G} 2(\mathrm{MP} 2)^{32}, \quad \mathrm{MP} 2 / 6-311++\mathrm{G}(\mathrm{d}, \mathrm{p})^{31}, \quad\right.$ PMP4SDTQ/6$311 \mathrm{G}(\mathrm{d}, \mathrm{p}) / / \mathrm{MP} 2 / 6-31 \mathrm{G}(\mathrm{d}, \mathrm{p})^{33}$ and $\operatorname{CCSD}(\mathrm{T}) / 6-311++\mathrm{G}(\mathrm{d}, \mathrm{p})^{31}$ and $\operatorname{CCSD}(\mathrm{T}) / \mathrm{Aug}-\mathrm{cc}-$ $\left.\mathrm{pV}(\mathrm{Q}+\mathrm{d}) \mathrm{Z} / / \mathrm{CCSD}(\mathrm{T}) / 6-311++\mathrm{G}(2 \mathrm{df}, \mathrm{p})^{34}\right)$ computational results, which in all cases indicate the methoxysulfinyl isomer is the ground-state structure. Therefore, $\mathrm{CH}_{3} \mathrm{OSO}$ is considered as the fragmentation product in reaction 2. Previous computational calculations have estimated the energy for rearrangement from $\mathrm{CH}_{3} \mathrm{SO}_{2}$ to $\mathrm{CH}_{3} \mathrm{OSO}$ to be between 98 and $222 \mathrm{~kJ}^{\mathrm{mol}}{ }^{-1}$, 
depending on the level of theory. ${ }^{31,32}$ It is unlikely that such a rearrangement would occur under the present experimental conditions. However, in view of the small energy difference between the two isomers, interpretation of the results is not affected by consideration of the (slightly) lower-energy rearrangement isomer. The energies required for loss of $\mathrm{CH}_{3} \mathrm{SO}_{2}{ }^{-}$are 222-243 $\mathrm{kJ} \cdot \mathrm{mol}^{-1}$ for the three computed Ln complexes, which are higher in energy than those for the $\mathrm{CH}_{3}$-loss reaction. It is much more endothermic for $\mathrm{La}\left(\mathrm{CH}_{3} \mathrm{SO}_{2}\right)_{4}{ }^{-}$and $\mathrm{Lu}\left(\mathrm{CH}_{3} \mathrm{SO}_{2}\right)_{4}{ }^{-}$to lose a neutral $\mathrm{CH}_{3} \mathrm{OSO}$ ligand, processes computed to be endothermic by more than $400 \mathrm{~kJ}^{\mathrm{mol}}{ }^{-1}$. In contrast, neutral ligand loss for $\mathrm{Yb}\left(\mathrm{CH}_{3} \mathrm{SO}_{2}\right)_{4}{ }^{-}$is endothermic by only $203 \mathrm{~kJ} \cdot \mathrm{mol}^{-1}, 20 \mathrm{~kJ} \cdot \mathrm{mol}^{-1}$ lower in energy than the loss of anionic $\mathrm{CH}_{3} \mathrm{SO}_{2}{ }^{-}$. As shown in reactions 2 and 3, neutral $\mathrm{CH}_{3} \mathrm{OSO}$ loss results in the formation of $\mathrm{Ln}\left(\mathrm{CH}_{3} \mathrm{SO}_{2}\right)_{3}{ }^{-}$with a divalent $\mathrm{Ln}(\mathrm{II})$, whereas neutral $\mathrm{Ln}\left(\mathrm{CH}_{3} \mathrm{SO}_{2}\right)_{3}$ with a trivalent $\mathrm{Ln}(\mathrm{III})$ is formed upon $\mathrm{CH}_{3} \mathrm{SO}_{2}{ }^{-}$loss. For lanthanides, the oxidation state $\operatorname{Ln}(\mathrm{III})$ is accessible in all cases, while the oxidation state $\operatorname{Ln}(\mathrm{II})$ is most commonly observed for $\mathrm{Ln}=\mathrm{Eu}, \mathrm{Yb}$ and $\mathrm{Sm} \cdot{ }^{35}$ As the CID results reveal, it is more favorable to form complexes retaining the $\operatorname{Ln}(\mathrm{III})$ oxidation state for most of the lanthanides, with the exceptions of $\mathrm{Eu}, \mathrm{Yb}$ and $\mathrm{Sm}$. Our computed energetics for ligand loss reactions are in accord with this trend. Since loss of $\mathrm{CH}_{3} \mathrm{OSO}$ to form $\mathrm{Yb}\left(\mathrm{CH}_{3} \mathrm{SO}_{2}\right)_{3}{ }^{-}$is endothermic by only $203 \mathrm{~kJ} . \mathrm{mol}^{-1}$, this fragmentation channel becomes competitive with $\mathrm{CH}_{3}$ loss, resulting in the experimental observation of both $\mathrm{Yb}\left(\mathrm{CH}_{3} \mathrm{SO}_{2}\right)_{3}{ }^{-}$and $\mathrm{Yb}\left(\mathrm{CH}_{3} \mathrm{SO}_{2}\right)_{3}\left(\mathrm{SO}_{2}\right)^{-}$Based on the experimental results, it can be assumed that neutral $\mathrm{CH}_{3} \mathrm{OSO}$ loss should be least endothermic for $\mathrm{Eu}\left(\mathrm{CH}_{3} \mathrm{SO}_{2}\right)_{3}$, followed by $\mathrm{Yb}\left(\mathrm{CH}_{3} \mathrm{SO}_{2}\right)_{3}{ }^{-}$and then $\mathrm{Sm}\left(\mathrm{CH}_{3} \mathrm{SO}_{2}\right)_{3}{ }^{-}$, in accord with the decreasing (more negative) reduction potentials from $\mathrm{Eu}^{3+} / \mathrm{Eu}^{2+}$ to $\mathrm{Yb}^{3+} / \mathrm{Yb}^{2+}$ to $\mathrm{Sm}^{3+} / \mathrm{Sm}^{2+} \cdot{ }^{35}$ According to our computational results, loss of $\mathrm{CH}_{3} \mathrm{SO}_{2}^{-}$is a possible fragmentation pathway; however, the lowmass cutoff of the QIT/MS in CID mode precludes its detection. Although it is hypothetically feasible to infer the formation of $\mathrm{CH}_{3} \mathrm{SO}_{2}{ }^{-}$based on a diminishment in the total ion intensity, this approach was not practical in the present work due to a substantial reduction in ion intensity upon CID as a result of ion loss from the trap not due to fragmentation; such substantial ion loss upon any type of ion manipulation is routinely observed in our instrument.

The fragmentation patterns of $\mathrm{Ln}\left(\mathrm{CH}_{3} \mathrm{SO}_{2}\right)_{4}{ }^{-}$are quite different from those observed for copper complexes comprising the $\mathrm{CH}_{3} \mathrm{SO}_{2}{ }^{-}$ligand, for which loss of $\mathrm{SO}_{2}$ is predominant. ${ }^{11}$ Our computations indicate that the thermodynamically most favorable fragmentation reaction for $\mathrm{Cu}\left(\mathrm{CH}_{3} \mathrm{SO}_{2}\right)_{2}{ }^{-}$is loss of $\mathrm{SO}_{2}$ with formation of $\mathrm{Cu}\left(\mathrm{CH}_{3} \mathrm{SO}_{2}\right)\left(\mathrm{CH}_{3}\right)^{-}$(Table 1). This result is in 
accord with results from O'Hair and co-workers, ${ }^{11}$ and indicates that whereas the oxophilic lanthanides induce elimination of $\mathrm{CH}_{3}$ to produce complexes with the $\mathrm{SO}_{2}^{-}$ligand, copper contrastingly induces elimination of $\mathrm{SO}_{2}$ to yield organocopper complexes. QTAIM bond analysis was performed on all the $\mathrm{Ln}\left(\mathrm{CH}_{3} \mathrm{SO}_{2}\right)\left(\mathrm{CH}_{3}\right)^{-}(\mathrm{Ln}=\mathrm{La}, \mathrm{Yb}$ and $\mathrm{Lu})$ complexes and on $\mathrm{Cu}\left(\mathrm{CH}_{3} \mathrm{SO}_{2}\right)\left(\mathrm{CH}_{3}\right)^{-}$(Supporting Information, Table $\mathrm{S} 3$ ). The Ln-C bond critical point (bcp) has the characteristics of an ionic bond, with electron densities at the bond critical points $\left(\rho_{\mathrm{BCP}}\right)$ lower than 0.075 au., positive laplacians of the electron density at the BCPs $\left(\nabla^{2} \rho_{\mathrm{BCP}}\right)$, and total electronic energy densities $\left(\mathrm{H}_{\mathrm{BCP}}\right)$ that are very small and negative (between -0.0173 and -0.0025 au.). The delocalization indexes (DI) indicate that in all cases the number of electrons shared by the metal and oxygen atoms is very low $\left(<0.60 \mathrm{e}^{-}\right)$. The $\mathrm{Cu}-\mathrm{C}$ bond characteristics are also mainly ionic in nature; however, the charge density at the bcp roughly doubles the La-C value and is almost three times higher than the $\mathrm{Yb}-\mathrm{C}$ value. The delocalization number is also notably higher than the same value for the $\mathrm{Ln}-\mathrm{C}$ bonds (i.e. DI $(\mathrm{Cu}, \mathrm{C})=0.958)$. The negative partial (QTAIM) charge on the $\mathrm{C}$ atom involved in the Ln-C bond is significantly higher (ca. $-0.50 \mathrm{e}$ ) than the same quantity for the $\mathrm{Cu}-\mathrm{C}$ bond $\left(-0.15 \mathrm{e}^{-}\right)$.

The computations indicate that there are two isomers for the $\mathrm{SO}_{2}$ loss products, as shown in reactions 5 and 6.

$$
\begin{aligned}
& \mathrm{Ln}\left(\mathrm{CH}_{3} \mathrm{SO}_{2}\right)_{4}^{-} \rightarrow \mathrm{Ln}\left(\mathrm{CH}_{3} \mathrm{SO}_{2}\right)_{3}\left(\mathrm{CH}_{3}\right)^{-}+\mathrm{SO}_{2} \\
& \mathrm{Ln}\left(\mathrm{CH}_{3} \mathrm{SO}_{2}\right)_{4}^{-} \rightarrow \mathrm{Ln}\left(\mathrm{CH}_{3} \mathrm{SO}_{2}\right)_{2}\left(\mathrm{CH}_{3} \mathrm{SO}\right)\left(\mathrm{OCH}_{3}\right)^{-}+\mathrm{SO}_{2}
\end{aligned}
$$

The $\mathrm{Ln}\left(\mathrm{CH}_{3} \mathrm{SO}_{2}\right)_{2}\left(\mathrm{CH}_{3} \mathrm{SO}\right)\left(\mathrm{OCH}_{3}\right)^{-}$isomers $(\mathrm{Ln}=\mathrm{La}, \mathrm{Yb}, \mathrm{Lu})$ are computed to be ca. $80-100$ $\mathrm{kJ} . \mathrm{mol}^{-1}$ more stable than the $\mathrm{Ln}\left(\mathrm{CH}_{3} \mathrm{SO}_{2}\right)_{3}\left(\mathrm{CH}_{3}\right)$ isomers, and reaction 6 is thus the most thermodynamically favorable among the five reactions considered. Although $\mathrm{SO}_{2}$ loss was not observed, the barrier for the rearrangement of the hypothetical products of reactions 5 and 6 were computed. This evaluation provides a prototypical example of the role of kinetics in determining experimentally observed fragmentation pathways. Formation of the more stable $\mathrm{Ln}\left(\mathrm{CH}_{3} \mathrm{SO}_{2}\right)\left(\mathrm{CH}_{3} \mathrm{SO}\right)\left(\mathrm{OCH}_{3}\right)$ isomer would involve a significant reorganization of the ligands, which results in substantial energy barriers (Figure 5). The transition state for the transformation between the two isomers, $\mathrm{Ln}\left(\mathrm{CH}_{3} \mathrm{SO}_{2}\right)_{3}\left(\mathrm{CH}_{3}\right)^{-} \rightarrow \mathrm{Ln}\left(\mathrm{CH}_{3} \mathrm{SO}_{2}\right)_{2}\left(\mathrm{CH}_{3} \mathrm{SO}\right)\left(\mathrm{OCH}_{3}\right)^{-}$, involve significant reaction barriers, between 187 and $203 \mathrm{~kJ} \mathrm{~mol}^{-1}$ (Figure 5). These barriers explain 
why low-energy $\mathrm{SO}_{2}$ elimination (reaction 6) was not observed. In contrast, $\mathrm{CH}_{3}$ loss (reaction 1) is most likely barrierless, resulting in the appearance of $\mathrm{SO}_{2}$ adducts despite the greater endothermicity of this process. Although the reaction pathways for the elimination of $\mathrm{SO}_{2}$ were not analyzed in detail, the initial step for reaction 6 was studied for $\mathrm{Ln}=\mathrm{La}$, Lu. This process involves the transfer of the $\mathrm{CH}_{3}{ }^{-}$moiety from one of the ligands to an adjacent ligand, which consequently becomes monodentate. It was found that this process gives rise to significant energy barriers, i.e. the TS relative energies with respect to the $\mathrm{Ln}\left(\mathrm{CH}_{3} \mathrm{SO}_{2}\right)_{4}{ }^{-}$initial complex are higher than $300 \mathrm{~kJ} \mathrm{~mol}^{-1}$ (Supporting Information, figure S6). Despite that we have not studied the reaction barriers involved in a direct transfer of the $\mathrm{CH}_{3}$ moiety to the Ln cation, we anticipate higher barriers than those reported in Figure S6 considering the higher endothermicity (i.e. between 75 and $101 \mathrm{~kJ} \mathrm{~mol}^{-1}$ ) involved in the formation of the lanthanide organometallic products (Table 1).

\section{Reactions with Background $\mathrm{O}_{2}$}

When $\mathrm{Ln}\left(\mathrm{CH}_{3} \mathrm{SO}_{2}\right)_{3}\left(\mathrm{SO}_{2}\right)^{-}$was mass selected and allowed to react with background gases in the ion trap, a peak on the low $\mathrm{m} / \mathrm{z}$ side of $\mathrm{Ln}\left(\mathrm{CH}_{3} \mathrm{SO}_{2}\right)_{3}\left(\mathrm{SO}_{2}\right)^{-}(\mathrm{Ln}=\mathrm{La}-\mathrm{Lu}$, except Eu$)$ appeared; the examples of $\mathrm{Ln}=\mathrm{Sm}$ and $\mathrm{Tm}$ are shown in Figure 6. The difference of $32 \mathrm{~m} / \mathrm{z}$ indicates that the new species is $\mathrm{Ln}\left(\mathrm{CH}_{3} \mathrm{SO}_{2}\right)_{3}\left(\mathrm{O}_{2}\right)^{-}$, where the $\mathrm{SO}_{2}$ ligand has been replaced by background $\mathrm{O}_{2}$ in the ion trap. This process also results in the appearance of weak peaks (labeled $\mathrm{D}$ in Figure 3) during CID of $\mathrm{Ln}\left(\mathrm{CH}_{3} \mathrm{SO}_{2}\right)_{4}{ }^{-}$. The yield of $\mathrm{Ln}\left(\mathrm{CH}_{3} \mathrm{SO}_{2}\right)_{3}\left(\mathrm{O}_{2}\right)^{-}$increases substantially when $\mathrm{Ln}\left(\mathrm{CH}_{3} \mathrm{SO}_{2}\right)_{3}\left(\mathrm{SO}_{2}\right)^{-}$is isolated and a reaction time of $0.3 \mathrm{~s}$ is applied (Figure 6), confirming the spontaneous formation of dioxygen complexes. Since $\operatorname{Ln}($ III) is the most common oxidation state for all the lanthanides that form $\mathrm{Ln}\left(\mathrm{CH}_{3} \mathrm{SO}_{2}\right)_{3}\left(\mathrm{O}_{2}\right)^{-}$, it is reasonable to assume that the $\mathrm{O}_{2}$ ligand in this complex is a superoxide. Although the oxidation state IV is common for $\mathrm{Ce}^{36}$ the rather high reduction potential for $\mathrm{Ce}(\mathrm{IV}) / \mathrm{Ce}(\mathrm{III})(1.72 \mathrm{~V})^{34}$ makes it unlikely that $\mathrm{Ce}\left(\mathrm{CH}_{3} \mathrm{SO}_{2}\right)_{3}\left(\mathrm{O}_{2}\right)^{-}$is a $\mathrm{Ce}(\mathrm{IV})$ peroxo complex. Our recent investigations of the structure and reactivity of $\mathrm{UO}_{2}\left(\mathrm{CH}_{3} \mathrm{SO}_{2}\right)\left(\mathrm{SO}_{2}\right)^{-}$similarly revealed the formation of $\mathrm{UO}_{2}\left(\mathrm{CH}_{3} \mathrm{SO}_{2}\right)\left(\mathrm{O}_{2}\right)^{-}$during the reaction of $\mathrm{O}_{2}$ with $\mathrm{UO}_{2}\left(\mathrm{CH}_{3} \mathrm{SO}_{2}\right)\left(\mathrm{SO}_{2}\right)^{-10}$. The $\mathrm{O}_{2}$ ligand in this complex was characterized as peroxide on the basis of its bond length and vibrational frequency. In contrast to $\mathrm{Ce}$, the very low reduction potential for $\mathrm{U}^{\mathrm{VI}} \mathrm{O}_{2}{ }^{2+} / \mathrm{U}^{\mathrm{V}} \mathrm{O}_{2}{ }^{+}(0.062 \mathrm{~V})^{34}$ makes it relatively facile for $\mathrm{U}^{\mathrm{V}} \mathrm{O}_{2}{ }^{+}$to be oxidized to $\mathrm{U}^{\mathrm{VI}} \mathrm{O}_{2}{ }^{2+}$ to yield a peroxide complex. 
As shown in Figure 3, the CID behavior of $\mathrm{Yb}\left(\mathrm{CH}_{3} \mathrm{SO}_{2}\right)_{4}{ }^{-}, \mathrm{Sm}\left(\mathrm{CH}_{3} \mathrm{SO}_{2}\right)_{4}{ }^{-}$, and especially $\mathrm{Eu}\left(\mathrm{CH}_{3} \mathrm{SO}_{2}\right)_{4}{ }^{-}$, is quite different from the rest of the lanthanide analogs. While CID of $\mathrm{Eu}\left(\mathrm{CH}_{3} \mathrm{SO}_{2}\right)_{4}{ }^{-}$resulted exclusively in $\mathrm{Eu}\left(\mathrm{CH}_{3} \mathrm{SO}_{2}\right)_{3}{ }^{-}$, the yields of $\mathrm{Yb}\left(\mathrm{CH}_{3} \mathrm{SO}_{2}\right)_{3}{ }^{-}$and $\mathrm{Sm}\left(\mathrm{CH}_{3} \mathrm{SO}_{2}\right)_{3}{ }^{-}$are lower. These three lanthanide complexes exhibit the oxidation state $\mathrm{Ln}(\mathrm{II})$, which might be oxidized to $\mathrm{Ln}(\mathrm{III})$ upon reaction with $\mathrm{O}_{2}$. It has been demonstrated that $\mathrm{U}^{\mathrm{V}} \mathrm{O}_{2}{ }^{+}$ is spontaneously oxidized to the superoxide $\mathrm{U}^{\mathrm{VI}} \mathrm{O}_{2}\left(\mathrm{O}_{2}\right)^{+}$by $\mathrm{O}_{2}$ addition. ${ }^{19}$ Given that the reduction potentials of the $\mathrm{Ln}^{3+}$ ions are all below that of $\mathrm{U}^{\mathrm{VI}} \mathrm{O}_{2}{ }^{+35}$ it is predicted that spontaneous $\mathrm{O}_{2}$ addition should similarly oxidize $\mathrm{Ln}(\mathrm{II})$ to $\mathrm{Ln}(\mathrm{III})$. The $\mathrm{Eu}\left(\mathrm{CH}_{3} \mathrm{SO}_{2}\right)_{3}{ }^{-}$and $\mathrm{Yb}\left(\mathrm{CH}_{3} \mathrm{SO}_{2}\right)_{3}{ }^{-}$complexes were mass selected to assess their reactivity towards $\mathrm{O}_{2}$. The $\mathrm{Eu}\left(\mathrm{CH}_{3} \mathrm{SO}_{2}\right)_{3}\left(\mathrm{O}_{2}\right)^{-}$and $\mathrm{Yb}\left(\mathrm{CH}_{3} \mathrm{SO}_{2}\right)_{3}\left(\mathrm{O}_{2}\right)^{-}$complexes were apparent in the mass spectra after a reaction time of $0.5 \mathrm{~s}$ (Figure 7), but the yield of $\mathrm{Eu}\left(\mathrm{CH}_{3} \mathrm{SO}_{2}\right)_{3}\left(\mathrm{O}_{2}\right)^{-}$was lower than that of $\mathrm{Yb}\left(\mathrm{CH}_{3} \mathrm{SO}_{2}\right)_{3}\left(\mathrm{O}_{2}\right)^{-}$. No $\mathrm{O}_{2}$ adduct was observed without applying a reaction delay; the intensities of the precursor reactant ions were too low to obtain meaningful time-dependent reaction kinetics. The apparently lower reactivity of the $\mathrm{Eu}(\mathrm{II})$ complex is consistent with the fact that the $\mathrm{Eu}^{3+} / \mathrm{Eu}^{2+}$ reduction potential is about $0.7 \mathrm{~V}$ higher than that of $\mathrm{Yb}^{3+} / \mathrm{Yb}^{2+},{ }^{35}$ though it should be noted that after CID thermalization may not be effective such that the observed relative reaction efficiencies could be attributable to differences in internal energy that result in differences in adduct stabilization, rather than intrinsic reactivities. It was not possible to mass select $\mathrm{Sm}\left(\mathrm{CH}_{3} \mathrm{SO}_{2}\right)_{3}{ }^{-}$due to the low yield and multiple isotopes. However, based on the lower reduction potential of $\mathrm{Sm}^{3+} / \mathrm{Sm}^{2+}$, it should be more favorable for $\mathrm{Sm}\left(\mathrm{CH}_{3} \mathrm{SO}_{2}\right)_{3}{ }^{-}$to undergo oxidation and form $\mathrm{Sm}\left(\mathrm{CH}_{3} \mathrm{SO}_{2}\right)_{3}\left(\mathrm{O}_{2}\right)^{-}$, which results in the peak labeled D in Figure 3 during CID of $\mathrm{Sm}\left(\mathrm{CH}_{3} \mathrm{SO}_{2}\right)_{4}{ }^{-}$. In view of the high O-atom affinity of most lanthanides there should be an energetic propensity for the formation of $\mathrm{Ln}=\mathrm{O}$ bonds. Addition of $\mathrm{O}_{2}$ to $\mathrm{Ln}\left(\mathrm{CH}_{3} \mathrm{SO}_{2}\right)_{3}{ }^{-}$could hypothetically proceed via $\mathrm{O}-\mathrm{O}$ bond cleavage to yield $\mathrm{O}=\mathrm{Ln}\left(\mathrm{CH}_{3} \mathrm{SO}_{2}\right)_{2}\left(\mathrm{CH}_{3} \mathrm{SO}_{3}\right)^{-}$, where $\mathrm{CH}_{3} \mathrm{SO}_{3}{ }^{-}$is a mesylate anion ligand. However, the oxidation state in this product would be $\mathrm{Ln}(\mathrm{IV})$, which is inaccessible for most lanthanides, particularly for $\mathrm{Eu}, \mathrm{Yb}$ and $\mathrm{Sm}^{35}$

\section{Conclusions}

ESI of solutions containing lanthanide halides and $\mathrm{CH}_{3} \mathrm{SO}_{2} \mathrm{Na}$ resulted in the formation of $\mathrm{Ln}\left(\mathrm{CH}_{3} \mathrm{SO}_{2}\right)_{4}^{-}$in the gas phase. Subsequent $\mathrm{CID}$ of these complexes gave rise to $\mathrm{Ln}\left(\mathrm{CH}_{3} \mathrm{SO}_{2}\right)_{3}\left(\mathrm{SO}_{2}\right)^{-}$via loss of $\mathrm{CH}_{3}$, with the sole exception of $\mathrm{Eu}\left(\mathrm{CH}_{3} \mathrm{SO}_{2}\right)_{4}{ }^{-}$. DFT calculations 
indicate that $\mathrm{SO}_{2}$ acts as a bidentate ligand in $\mathrm{La}\left(\mathrm{CH}_{3} \mathrm{SO}_{2}\right)_{3}\left(\mathrm{SO}_{2}\right)^{-}$and $\mathrm{Lu}\left(\mathrm{CH}_{3} \mathrm{SO}_{2}\right)_{3}\left(\mathrm{SO}_{2}\right)^{-}$, with doublet ground spin states; $\mathrm{SO}_{2}$ monodentate isomers are close in energy (within $14 \mathrm{~kJ} \cdot \mathrm{mol}^{-1}$ ). The open-shell singlet $\mathrm{Yb}\left(\mathrm{CH}_{3} \mathrm{SO}_{2}\right)_{3}\left(\mathrm{SO}_{2}\right)^{-}$ground state has a monodentate $\mathrm{SO}_{2}$ ligand. Based on the optimized geometrical parameters and the distribution of the spin density, it is concluded that the $\mathrm{SO}_{2}$ ligand in these complexes is negatively charged, indicating that $\mathrm{Ln}\left(\mathrm{CH}_{3} \mathrm{SO}_{2}\right)_{3}\left(\mathrm{SO}_{2}\right)^{-}$ should be considered as $\mathrm{Ln}(\mathrm{III})$ complexes. All of the $\mathrm{Ln}\left(\mathrm{CH}_{3} \mathrm{SO}_{2}\right)_{3}\left(\mathrm{SO}_{2}\right)^{-}$complexes spontaneously react with $\mathrm{O}_{2}$ to form $\mathrm{Ln}\left(\mathrm{CH}_{3} \mathrm{SO}_{2}\right)_{3}\left(\mathrm{O}_{2}\right)^{-}$, presumably $\mathrm{Ln}$ (III) superoxo complexes. $\mathrm{CID}$ of $\mathrm{Eu}\left(\mathrm{CH}_{3} \mathrm{SO}_{2}\right)_{4}{ }^{-}$distinctively resulted in only $\mathrm{Eu}\left(\mathrm{CH}_{3} \mathrm{SO}_{2}\right)_{3}{ }^{-}$, with reduction from $\mathrm{Eu}$ (III) to $\mathrm{Eu}(\mathrm{II})$. Reduction was also observed upon $\mathrm{CID}$ of $\mathrm{Yb}\left(\mathrm{CH}_{3} \mathrm{SO}_{2}\right)_{4}{ }^{-}$and $\mathrm{Sm}\left(\mathrm{CH}_{3} \mathrm{SO}_{2}\right)_{4}$; the resulting $\mathrm{Yb}\left(\mathrm{CH}_{3} \mathrm{SO}_{2}\right)_{3}{ }^{-}$and $\mathrm{Sm}\left(\mathrm{CH}_{3} \mathrm{SO}_{2}\right)_{3}{ }^{-}$complexes exhibited $\mathrm{O}_{2}$-addition to produce $\mathrm{Yb}\left(\mathrm{CH}_{3} \mathrm{SO}_{2}\right)_{3}\left(\mathrm{O}_{2}\right)^{-}$and $\mathrm{Sm}\left(\mathrm{CH}_{3} \mathrm{SO}_{2}\right)_{3}\left(\mathrm{O}_{2}\right)^{-}$, in which the $\mathrm{Ln}(\mathrm{III})$ oxidation state is recovered. Computed energetics reveal that loss of $\mathrm{CH}_{3}$ is much more favorable than reduction via neutral ligand loss for $\mathrm{La}\left(\mathrm{CH}_{3} \mathrm{SO}_{2}\right)_{4}{ }_{4}$ and $\mathrm{Lu}\left(\mathrm{CH}_{3} \mathrm{SO}_{2}\right)_{4}{ }^{-}$, whereas both channels are close in energy for $\mathrm{Yb}\left(\mathrm{CH}_{3} \mathrm{SO}_{2}\right)_{4}$, consistent with the experimental observations. Unobserved loss of $\mathrm{SO}_{2}$ to form $\mathrm{Ln}\left(\mathrm{CH}_{3} \mathrm{SO}_{2}\right)_{3}\left(\mathrm{CH}_{3}\right)^{-}$, or the lower-energy $\mathrm{Ln}\left(\mathrm{CH}_{3} \mathrm{SO}_{2}\right)_{2}\left(\mathrm{CH}_{3} \mathrm{SO}\right)\left(\mathrm{OCH}_{3}\right)^{-}$isomer, were also analyzed computationally. Despite that it is the least endothermic fragmentation channel, high energy barriers to yield $\mathrm{Ln}\left(\mathrm{CH}_{3} \mathrm{SO}_{2}\right)_{2}\left(\mathrm{CH}_{3} \mathrm{SO}\right)\left(\mathrm{OCH}_{3}\right)^{-}$render it inaccessible upon CID.

The results for the lanthanide complexes reflect the relative stabilities of the $\operatorname{Ln}$ (II) oxidation states, as indicated by the $\mathrm{Ln}^{3+} / \mathrm{Ln}^{2+}$ reduction potentials. The greatest propensity towards reduction was exhibited by $\mathrm{Eu}(\mathrm{III})$, with lesser reduction of $\mathrm{Yb}(\mathrm{III})$ and $\mathrm{Sm}(\mathrm{III})$, and no reduction of the other $\mathrm{Ln}(\mathrm{III})$. The computed energetics for reactions of $\mathrm{La}(\mathrm{III}), \mathrm{Lu}(\mathrm{III})$ and $\mathrm{Yb}$ (III) complexes are also in accord with the higher (less negative) $\mathrm{Yb}^{3+} / \mathrm{Yb}^{2+}$ reduction potential. The computed energetics for $\mathrm{Cu}\left(\mathrm{CH}_{3} \mathrm{SO}_{2}\right)_{2}{ }^{-}$are in accord with the formation of organocopper complexes. The chemistry of the $\mathrm{Ln}\left(\mathrm{CH}_{3} \mathrm{SO}_{2}\right)_{4}{ }^{-}$complexes, which do not form organolanthanides, reflects the "hard" oxophilic character of the lanthanides, in contrast to "softer" transition metals such as copper.

Changes in oxidation state of gas-phase complexes can be evaluated based on reduction potentials or ionization energies. In the present work we have considered the relative stabilities of the $\mathrm{Ln}(\mathrm{III})$ and $\mathrm{Ln}(\mathrm{II})$ oxidation states as indicated by the $\mathrm{Ln}^{3+} / \mathrm{Ln}^{2+}$ reduction potentials. Alternatively, comparisons can be made by considering the $\mathrm{Ln}^{2+} \rightarrow \mathrm{Ln}^{3+}$ ionization energies (IE3), which generally correlate with the $\mathrm{Ln}^{3+} / \mathrm{Ln}^{2+}$ reduction potentials. ${ }^{37,38}$ Although usually a higher 
IE3 predicts a higher $\mathrm{Ln}^{3+} / \mathrm{Ln}^{2+}$ reduction potential, there are deviations from this correlation. In particular, IE3[Yb] is ca. $0.1 \mathrm{~V}$ higher than IE3[Eu], whereas the $\mathrm{Yb}^{3+} / \mathrm{Yb}^{2+}$ reduction potential is ca. $0.7 \mathrm{~V}$ lower than the $\mathrm{Eu}^{3+} / \mathrm{Eu}^{2+}$ reduction potential. ${ }^{35}$ The present results suggest that it is the condensed phase redox behavior, i.e. the $\mathrm{Ln}^{3+} / \mathrm{Ln}^{2+}$ reduction potentials, rather than the gasphase atomic ionization energies, which better predict behavior in gas-phase coordination complexes. This is consistent with the retention of chemical bonding, as opposed to electron removal by ionization, in coordination complexes, regardless of whether they are in gas or condensed phase.

\section{Acknowledgements}

The work of YG and JKG was fully supported by the U.S. Department of Energy, Office of Basic Energy Sciences, Heavy Element Chemistry, at LBNL under Contract No. DE-AC0205CH11231. MCM acknowledges support by the Università della Calabria. This research used resources of the National Energy Research Scientific Computing Center (NERSC), which is supported by the Office of Science of the U.S. Department of Energy under Contract No. DEAC02-05CH11231.

\section{References}

(1) Mews, R.; Lork, E.; Watson, P. G.; Gortler, B.: Coordination Chemistry in and of Sulfur Dioxide. Coordination Chemistry Reviews 2000, 197, 277-320.

(2) Albrecht, M.; Lutz, M.; Spek, A. L.; van Koten, G.: Organoplatinum Crystals for GasTriggered Switches. Nature 2000, 406, 970-974.

(3) Albrecht, M.; Gossage, R. A.; Lutz, M.; Spek, A. L.; van Koten, G.: Diagnostic Organometallic and Metallodendritic Materials for $\mathrm{SO}_{2}$ Gas Detection: Reversible Binding of Sulfur Dioxide to Arylplatinum(II) Complexes. Chemistry-a European Journal 2000, 6, 1431-1445.

(4) Schenk, W. A.: The Coordination Chemistry of Small Sulfur-Containing Molecules: a Personal Perspective. Dalton Transactions 2011, 40, 1209-1219.

(5) Amgoune, A.; Bourissou, D.: sigma-Acceptor, Z-type Ligands for Transition Metals. Chemical Communications 2011, 47, 859-871.

(6) Petersen, J.; Lork, E.; Mews, R.: Synthesis and Structure of $\{[\mathrm{Gd}(\mathrm{OSO})(3)(\mathrm{mu}-$ F2AsF4)(6/2)]center dot 0.25SO(2)\}(m). Chemical Communications 1996, 2593-2594.

(7) Benndorf, P.; Schmitt, S.; Koppe, R.; Ona-Burgos, P.; Scheurer, A.; Meyer, K.; Roesky, P. W.: Catching Gaseous $\mathrm{SO}_{2}$ in Cone-Type Lanthanide Complexes: An Unexpected Coordination Mode for $\mathrm{SO}_{2}$ in f-Element Chemistry. Angewandte Chemie-International Edition 2012, 51, 5006-5010.

(8) O'Hair, R. A. J.: The 3D Quadrupole Ion Trap Mass Spectrometer as a Complete Chemical Laboratory for Fundamental Gas-Phase Studies of Metal Mediated Chemistry. Chemical Communications 2006, 1469-1481. 
(9) O'Hair, R. A. J.: Gas Phase Ligand Fragmentataion to Unmask Reactive Metallic Species. In Reactive Intermediates; Santos, L. S., Ed.; Wiley-VCH Verlag GmbH \& Co. KGaA: Weinheim, Germany, 2010.

(10) Gong, Y.; Gibson, J. K.: Formation and Characterization of the Uranyl-SO ${ }_{2}$ Complex, $^{2}$ $\mathrm{UO}_{2}\left(\mathrm{CH}_{3} \mathrm{SO}_{2}\right)\left(\mathrm{SO}_{2}\right)(-)$. Journal of Physical Chemistry $A$ 2013, 117, 783-787.

(11) Sraj, L. O.; Khairallah, G. N.; da Silva, G.; O'Hair, R. A. J.: Who Wins: Pesci, Peters, or Deacon? Intrinsic Reactivity Orders for Organocuprate Formation via Ligand Decomposition. Organometallics 2012, 31, 1801-1807.

(12) Denning, R. G.: Electronic Structure and Bonding in Actinyl lons and their Analogs. Journal of Physical Chemistry A 2007, 111, 4125-4143.

(13) Rios, D.; Rutkowski, P. X.; Shuh, D. K.; Bray, T. H.; Gibson, J. K.; Van Stipdonk, M. J.: Electron Transfer Dissociation of Dipositive Uranyl and Plutonyl Coordination Complexes. Journal of Mass Spectrometry 2011, 46, 1247-1254.

(14) Gong, Y.; Vallet, V.; Michelini, M. D.; Rios, D.; Gibson, J. K.: Activation of Gas-Phase Uranyl: From an Oxo to a Nitrido Complex. Journal of Physical Chemistry A 2014, 118, 325-330.

(15) Gong, Y.; Tian, G. X.; Rao, L. F.; Gibson, J. K.: Dissociation of Diglycolamide Complexes of $\mathrm{Ln}(3+)(\mathrm{Ln}=\mathrm{La}-\mathrm{Lu})$ and $\mathrm{An}(3+)(\mathrm{An}=\mathrm{Pu}, \mathrm{Am}, \mathrm{Cm})$ : Redox Chemistry of $4 \mathrm{f}$ and $5 \mathrm{f}$ Elements in the Gas Phase Parallels Solution Behavior. Inorganic Chemistry 2014, 53, 12135-12140.

(16) Gong, Y.; de Jong, W. A.; Gibson, J. K.: Gas Phase Uranyl Activation: Formation of a Uranium Nitrosyl Complex from Uranyl Azide. Journal of the American Chemical Society 2015, 137, 5911 5915.

(17) Gronert, S.: Estimation of Effective Ion Temperatures in a Quadrupole Ion Trap. Journal of the American Society for Mass Spectrometry 1998, 9, 845-848.

(18) Rutkowski, P. X.; Michelini, M. C.; Bray, T. H.; Russo, N.; Marçalo, J.; Gibson, J. K.: Hydration of Gas-Phase Ytterbium Ion Complexes Studied by Experiment and Theory. Theoretical Chemistry Accounts 2011, 129, 575-592.

(19) Rios, D.; Michelini, M. C.; Lucena, A. F.; Marcalo, J.; Bray, T. H.; Gibson, J. K.: Gas-Phase Uranyl, Neptunyl, and Plutonyl: Hydration and Oxidation Studied by Experiment and Theory. Inorganic Chemistry 2012, 51, 6603-6614.

(20) Perdew, J. P.; Burke, K.; Ernzerhof, M.: Generalized Gradient Approximation Made Simple. Physical Review Letters 1996, 77, 3865-3868.

(21) te Velde, G.; Bickelhaupt, F. M.; Baerends, E. J.; Guerra, C. F.; Van Gisbergen, S. J. A.; Snijders, J. G.; Ziegler, T.: Chemistry with ADF. Journal of Computational Chemistry 2001, 22, 931-967.

(22) Guerra, C. F.; Snijders, J. G.; te Velde, G.; Baerends, E. J.: Towards an Order-N DFT Method. Theoretical Chemistry Accounts 1998, 99, 391-403.

(23) Zhao, Y.; Truhlar, D. G.: A New Local Density Functional for Main-Group Thermochemistry, Transition Metal Bonding, Thermochemical Kinetics, and Noncovalent Interactions. Journal of Chemical Physics 2006, 125, 194101.

(24) Kuchle, W.; Dolg, M.; Stoll, H.; Preuss, H.: Energy-Adjusted Pseudopotentials for the Actinides - Parameter Sets and Test Calculations for Thorium and Thorium Monoxide. Journal of Chemical Physics 1994, 100, 7535-7542.

(25) Zhao, Y.; Truhlar, D. G.: The M06 Suite of Density Functionals for Main Group Thermochemistry, Thermochemical Kinetics, Noncovalent Interactions, Excited States, and Transition Elements: Two New Functionals and Systematic Testing of Four M06-Class Functionals and 12 Other Functionals. Theoretical Chemistry Accounts 2008, 120, 215-241.

(26) Zhao, Y.; Truhlar, D. G.: Density Functionals with Broad Applicability in Chemistry. Accounts of Chemical Research 2008, 41, 157-167. 
1990.

(28) Keith, T. A.: AIMAll (version 13.05.06), 2013 (aim.tkgristmill.com).

(29) Ray, A.; Vassalli, I.; Laverdet, G.; LeBras, G.: Kinetics of the Thermal Decomposition of the $\mathrm{CH}_{3} \mathrm{SO}_{2}$ Radical and its Reaction with $\mathrm{NO}_{2}$ at 1 torr and $298 \mathrm{~K}$. Journal of Physical Chemistry 1996, 100, 8895-8900.

(30) Chu, L.-K.; Lee, Y.-P.: Infrared Absorption of $\mathrm{CH}_{3} \mathrm{SO}_{2}$ detected with time-resolved Fouriertransform Spectroscopy. Journal of Chemical Physics 2006, 124, 244301-2244301(8).

(31) Li, X.; Meng, L.; Zeng, Y.; Zheng, S.: Isomerizations of $\mathrm{CH}_{3} \mathrm{SO}_{2}$ : Quantum Chemistry and Topological Study. Chin. J. Chem. 2010, 28, 896-900.

(32) Frank, A. J.; Turcek, F.: Methylsulfonyl and Methoxysulfinyl Radicals and Cations in the Gas Phase. A Variable-Time and Photoexcitation Neutralization-Reionization Mass Spectrometric and ab Initio/RRKM Study. Journal of Physical Chemistry A 1999, 103, 5348-5361.

(33) Davis, S. R.: Ab Initio Study of the Relative Energies of the Methylsulfonyl and Methoxysulfinyl Radicals. Journal of Physical Chemistry 1993, 97, 7535-7539.

(34) Rattliff, B. J.; Tang, X.; Butler, L. J.; Szpunar, D. E.; Lau, K.-C.: Determining the CH3SO2 -$>\mathrm{CH} 3+\mathrm{SO} 2$ barrier from methylsulfonyl chloride photodissociation at $193 \mathrm{~nm}$ using velocity map imaging. Journal of Chemical Physics 2009, 131, 0044304-0044304(15).

(35) Morss, L. R.: Thermochemical Properties of Yttrium, Lanthanum, and Lanthanide Elements and lons. Chemical Reviews 1976, 76, 827-841.

(36) Mikulas, T.; Chen, M. Y.; Dixon, D. A.; Peterson, K. A.; Gong, Y.; Andrews, L.: Reactions of Lanthanide Atoms with Oxygen Difluoride and the Role of the Ln Oxidation State. Inorganic Chemistry 2014, 53, 446-456.

(37) Lide, D. R.: CRC Handbook of Chemistry and Physics; CRC: Boca Raton, Fl, 2009-2010.

(38) Bratsch, S. G.; Lagowski, J. J.: Lanthanide Thermodynamic Predictions .7.

Thermodynamics of 2+, 3+, and 4+ Aquo lons and Standard Electrode-Potentials at 298.15-K. Journal of Physical Chemistry 1985, 89, 3317-3319.

(39) Bratsch, S. G.; Lagowski, J. J.: Lanthanide Thermodynamic Predictions .6. Thermodynamics of Gas-Phase lons and Revised Enthalpy Equations for Solids at 298.15-K. Journal of Physical Chemistry 1985, 89, 3310-3316.

Table 1. $\mathrm{Ln}\left(\mathrm{CH}_{3} \mathrm{SO}_{2}\right)_{4}{ }^{-}$and $\mathrm{Cu}\left(\mathrm{CH}_{3} \mathrm{SO}_{2}\right)_{2}{ }^{-}$computed dissociation energies. ${ }^{a}$

\begin{tabular}{|l|c|c|c|c|c|}
\hline & $\begin{array}{c}\mathrm{CH}_{3} \text { loss } \\
\text { (reaction 1) }\end{array}$ & $\begin{array}{c}\mathrm{CH}_{3} \mathrm{SO}_{2} \text { loss } \\
\text { (reaction 2) }\end{array}$ & $\begin{array}{c}\mathrm{CH}_{3} \mathrm{SO}_{2}^{-} \text {loss } \\
\text { (reaction 3) }\end{array}$ & $\begin{array}{c}\mathrm{SO}_{2} \text { loss with } \\
\text { formation of } \mathrm{Ln}-\mathrm{CH}_{3} \\
\text { (reaction 5) }\end{array}$ & $\begin{array}{c}\mathrm{SO}_{2} \text { loss with } \\
\text { formation of } \mathrm{Ln}-\mathrm{OCH}_{3} \\
\text { (reaction 6) }\end{array}$ \\
\hline $\mathrm{La}\left(\mathrm{CH}_{3} \mathrm{SO}_{2}\right)_{4}^{-}$ & 193 & 410 & 243 & 240 & 139 \\
\hline $\mathrm{Yb}\left(\mathrm{CH}_{3} \mathrm{SO}_{2}\right)_{4}^{-}$ & 154 & 203 & 223 & 194 & 118 \\
\hline $\mathrm{Lu}\left(\mathrm{CH}_{3} \mathrm{SO}_{2}\right)_{4}^{-}$ & 194 & 436 & 222 & 218 & 134 \\
\hline
\end{tabular}




\begin{tabular}{|l|l|l|l|l|l|}
\hline $\mathrm{Cu}\left(\mathrm{CH}_{3} \mathrm{SO}_{2}\right)_{2}^{-}$ & 179 & 341 & 259 & 108 & 129 \\
\hline
\end{tabular}

${ }^{a} \mathrm{Ln}=\mathrm{La}, \mathrm{Yb}, \mathrm{Lu}$. Energies in $\mathrm{kJ} . \mathrm{mol}^{-1}$. M06-L/SDD single point calculations were performed on PBEZORA/TZ2P optimized structures (M06-L/SDD// PBE-ZORA/TZ2P). 


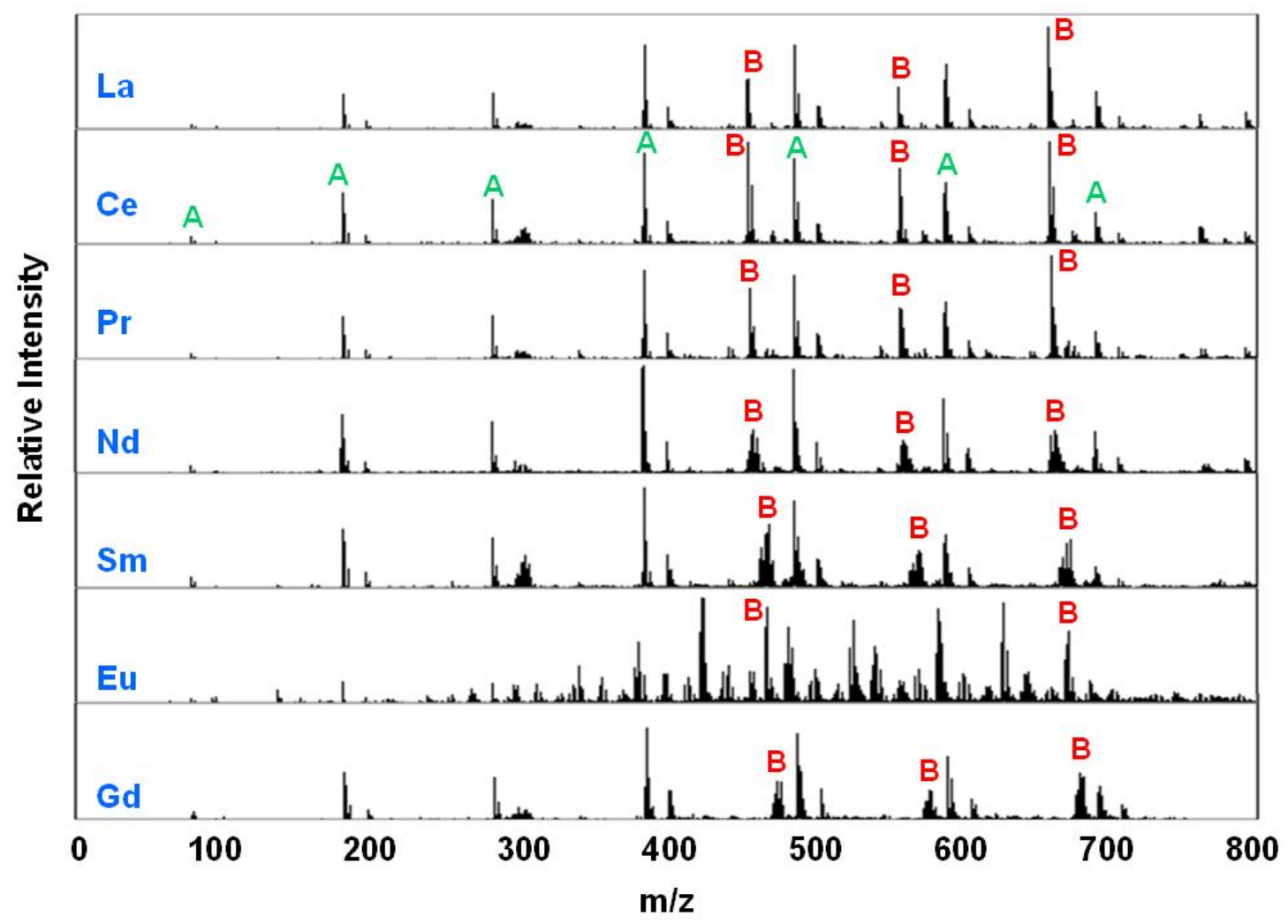

Figure 1. ESI mass spectra for mixtures of $\mathrm{LnX}_{3}(\mathrm{X}=\mathrm{Br}$ for $\mathrm{La}, \mathrm{Ce}, \mathrm{Pr}, \mathrm{Nd}, \mathrm{Sm}$ and $\mathrm{Gd} ; \mathrm{X}=\mathrm{Cl}$ for $\mathrm{Eu}$ ) and $\mathrm{CH}_{3} \mathrm{SO}_{2} \mathrm{Na}$. A: $\mathrm{CH}_{3} \mathrm{SO}_{2}{ }^{-}\left(\mathrm{CH}_{3} \mathrm{SO}_{2} \mathrm{Na}\right)_{\mathrm{x}}(\mathrm{x}=0-6)$; $\mathrm{B}: \mathrm{Ln}\left(\mathrm{CH}_{3} \mathrm{SO}_{2}\right) 4\left(\mathrm{CH}_{3} \mathrm{SO}_{2} \mathrm{Na}\right)_{\mathrm{y}}{ }^{-}(\mathrm{y}=0-2)$. 


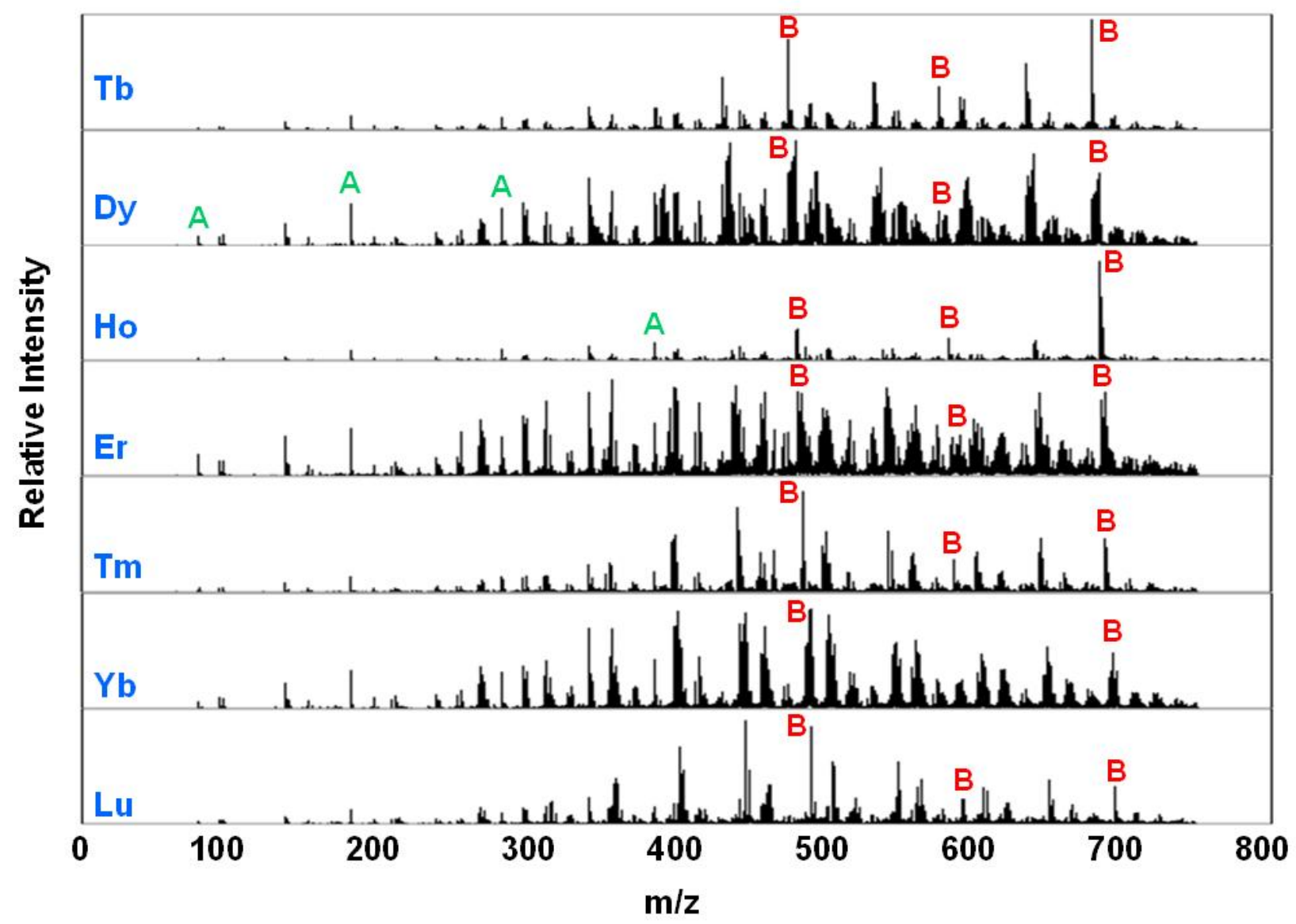

Figure 2. ESI mass spectra of mixtures of $\mathrm{LnCl}_{3}(\mathrm{Ln}=\mathrm{Tb}-\mathrm{Lu})$ and $\mathrm{CH}_{3} \mathrm{SO}_{2} \mathrm{Na}$. A: $\mathrm{CH}_{3} \mathrm{SO}_{2}{ }^{-}$ $\left(\mathrm{CH}_{3} \mathrm{SO}_{2} \mathrm{Na}\right)_{\mathrm{x}}(\mathrm{x}=0-3)$; $\mathrm{B}: \mathrm{Ln}\left(\mathrm{CH}_{3} \mathrm{SO}_{2}\right)_{4}\left(\mathrm{CH}_{3} \mathrm{SO}_{2} \mathrm{Na}\right)_{\mathrm{y}}{ }^{-}(\mathrm{y}=0-2)$. 


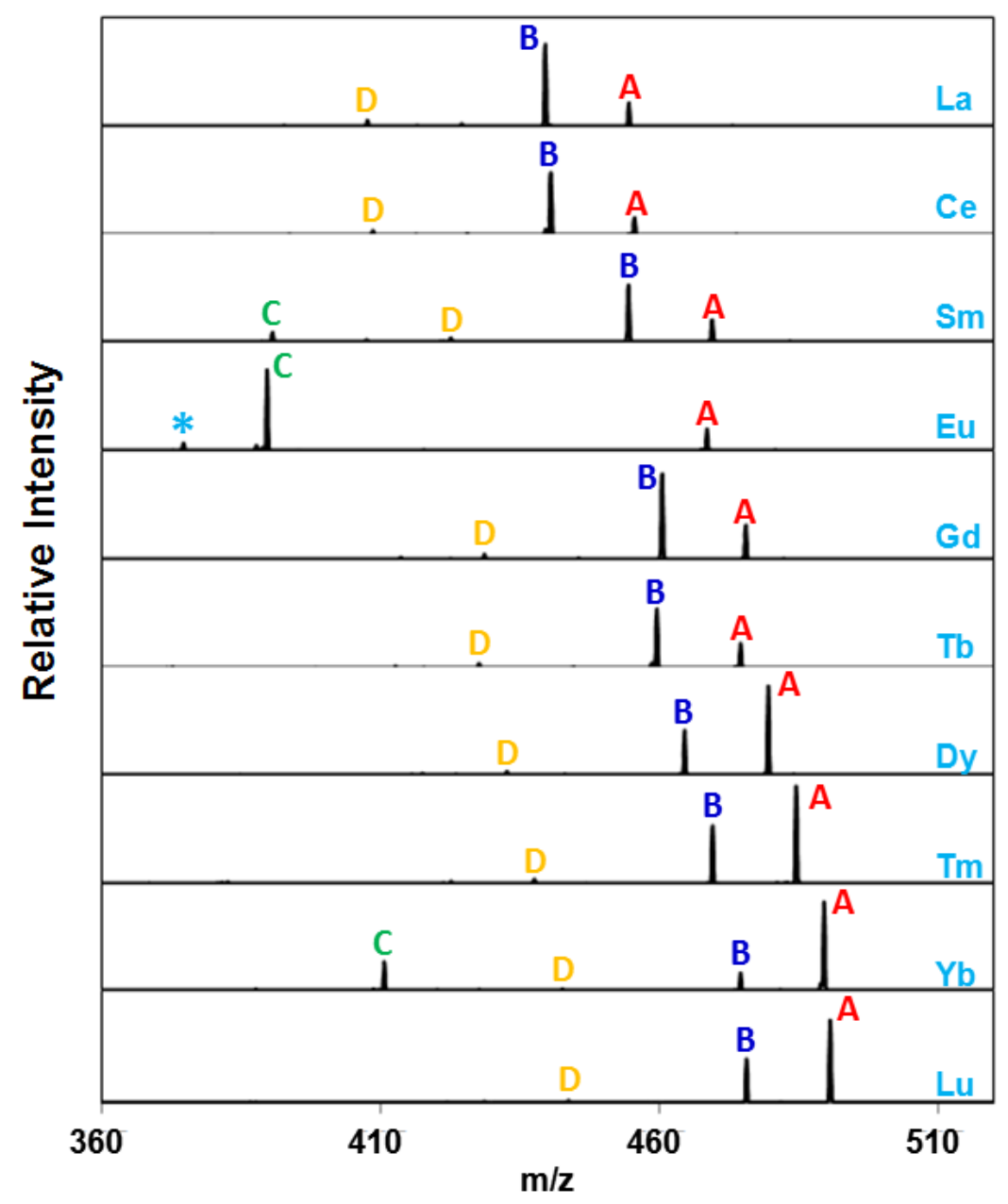

Figure 3. CID mass spectra of selected $\mathrm{Ln}\left(\mathrm{CH}_{3} \mathrm{SO}_{2}\right)_{4}^{-}$(CID conditions: $0.6 \mathrm{~V}$ applied for $\left.40 \mathrm{~ms}\right)$. A: $\operatorname{Ln}\left(\mathrm{CH}_{3} \mathrm{SO}_{2}\right)_{4}{ }^{-} ; \mathrm{B}: \operatorname{Ln}\left(\mathrm{CH}_{3} \mathrm{SO}_{2}\right)_{3}\left(\mathrm{SO}_{2}\right)^{-} ; \mathrm{C}: \operatorname{Ln}\left(\mathrm{CH}_{3} \mathrm{SO}_{2}\right)_{3}{ }^{-} ; \mathrm{D}: \operatorname{Ln}\left(\mathrm{CH}_{3} \mathrm{SO}_{2}\right)_{3}\left(\mathrm{O}_{2}\right)^{-}$. The asterisked peak is due to $\mathrm{Eu}\left(\mathrm{CH}_{3} \mathrm{SO}_{2}\right)_{2}\left(\mathrm{SO}_{2}\right)^{-}$. 

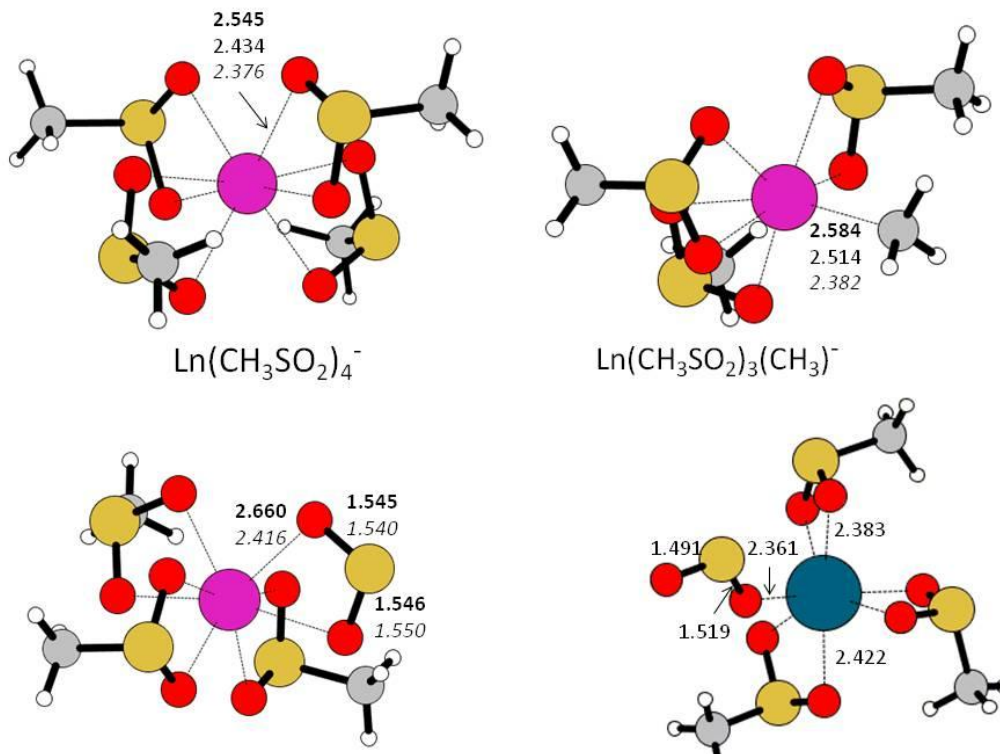

$\mathrm{Ln}\left(\mathrm{CH}_{3} \mathrm{SO}_{2}\right)_{3}\left(\mathrm{SO}_{2}\right)^{-} ; \mathrm{Ln}=\mathrm{La}, \mathrm{Lu}$
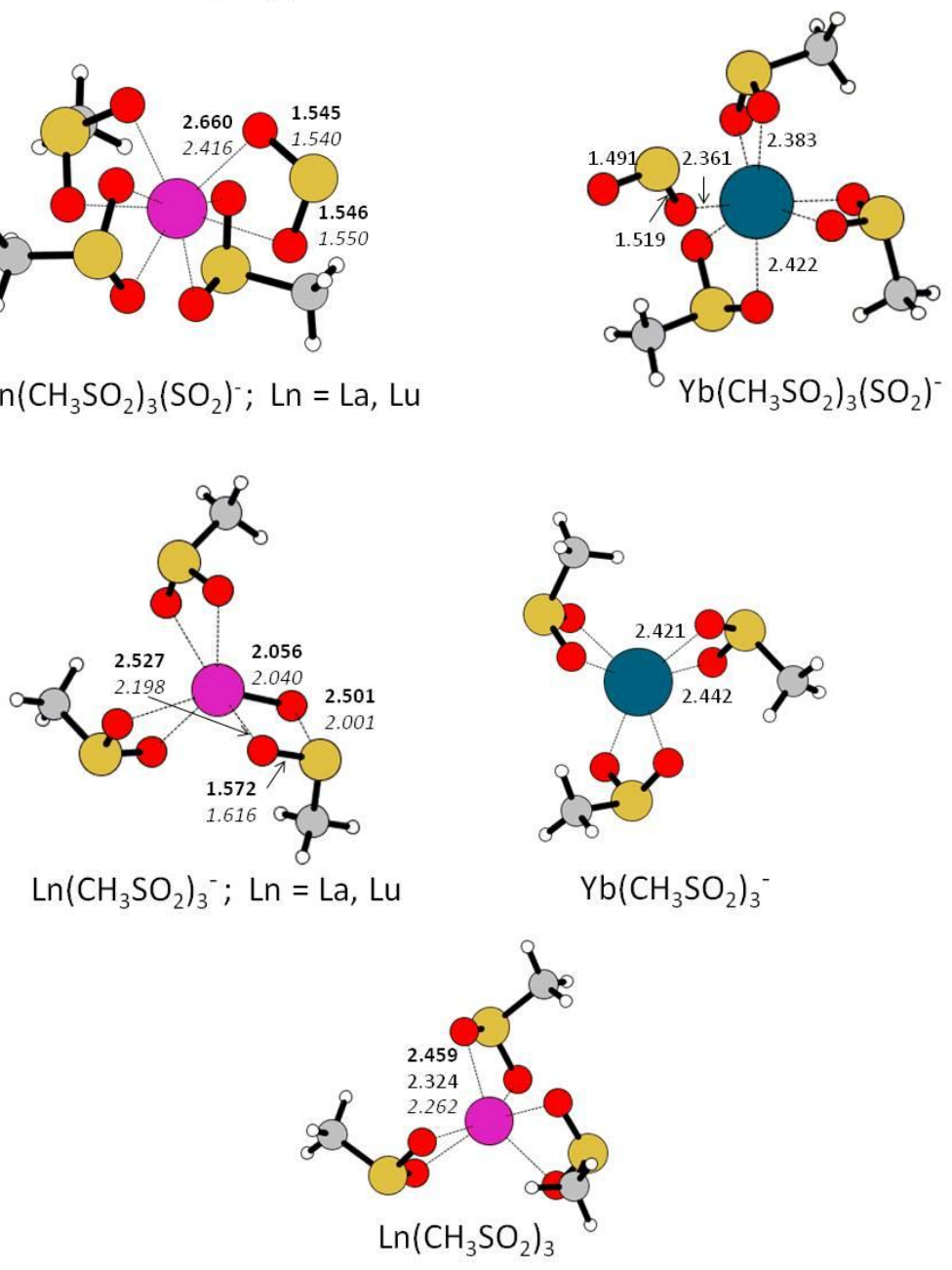

Figure 4. Selected geometrical parameters of $\mathrm{Ln}\left(\mathrm{CH}_{3} \mathrm{SO}_{2}\right)_{4}{ }^{-}$and its dissociations products for $\mathrm{Ln}=\mathrm{La}$ (bold), $\mathrm{Yb}$, and Lu (italics). Distances are in angstroms. 
(a)

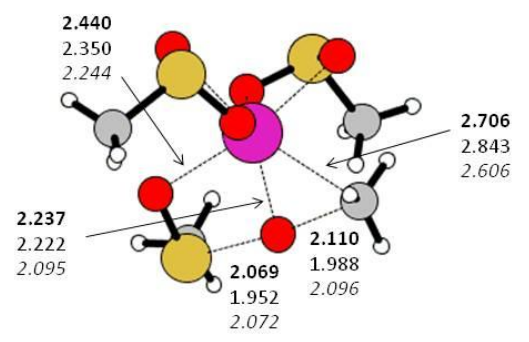

TS

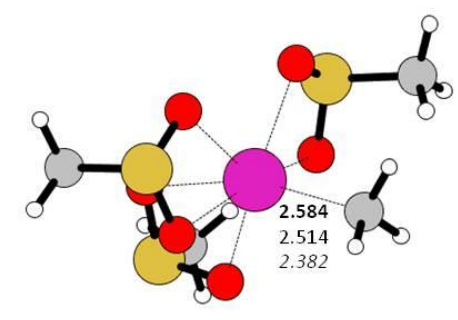

$\operatorname{Ln}\left(\mathrm{CH}_{3} \mathrm{SO}_{2}\right)_{3}\left(\mathrm{CH}_{3}\right)^{-}$

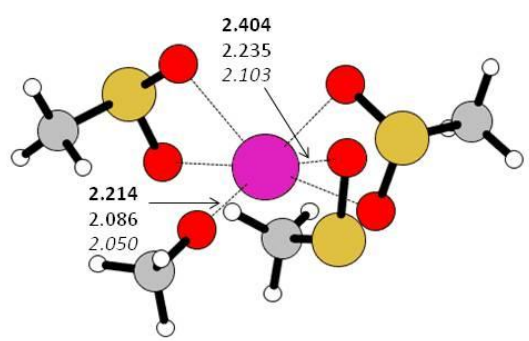

$\operatorname{Ln}\left(\mathrm{CH}_{3} \mathrm{SO}_{2}\right)_{2}\left(\mathrm{CH}_{3} \mathrm{SO}\right)\left(\mathrm{OCH}_{3}\right)^{-}$

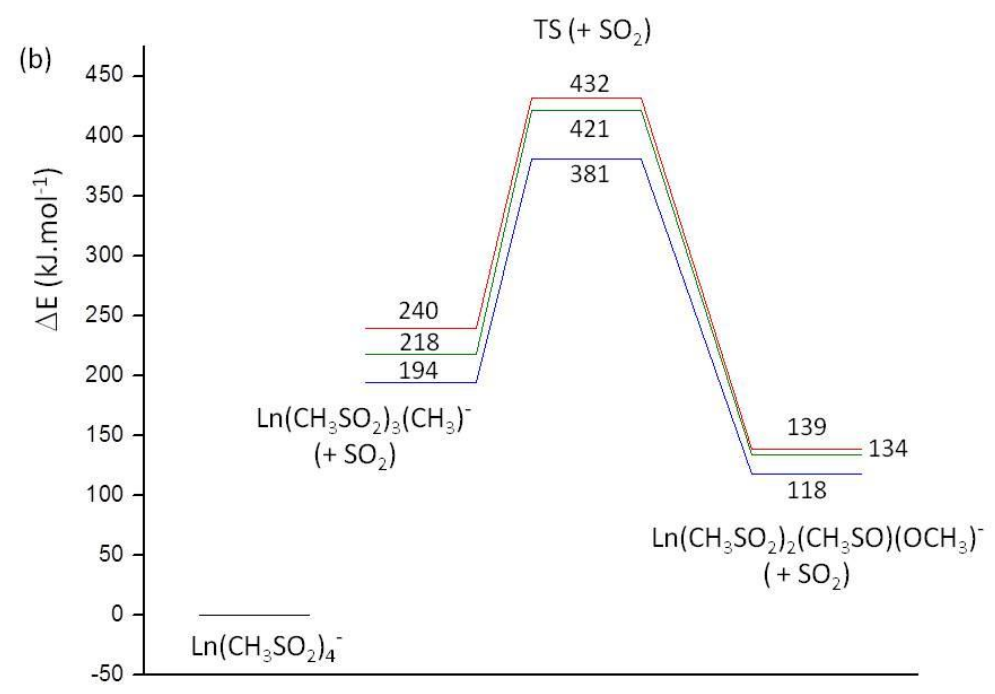

Figure 5. (a) $\mathrm{Ln}\left(\mathrm{CH}_{3} \mathrm{SO}_{2}\right)_{3}\left(\mathrm{CH}_{3}\right)^{-}$and $\mathrm{Ln}\left(\mathrm{CH}_{3} \mathrm{SO}_{2}\right)_{2}\left(\mathrm{OCH}_{3}\right)\left(\mathrm{CH}_{3} \mathrm{SO}\right)^{-}$isomers, and the connecting transition states at the M06-L/SDD//PBE-ZORA/TZ2P level of theory. TS imaginary frequencies are: $482 i \mathrm{~cm}^{-1}(\mathrm{La}), 517 i \mathrm{~cm}^{-1}(\mathrm{Yb})$, and $503 i \mathrm{~cm}^{-1}(\mathrm{Lu})$. Distances are in angstroms ( $\mathrm{La}$ in bold and $\mathrm{Lu}$ in italics). (b) $\mathrm{Ln}\left(\mathrm{CH}_{3} \mathrm{SO}_{2}\right)_{3}\left(\mathrm{CH}_{3}\right)^{-}$, $\mathrm{Ln}\left(\mathrm{CH}_{3} \mathrm{SO}_{2}\right)_{2}\left(\mathrm{OCH}_{3}\right)\left(\mathrm{CH}_{3} \mathrm{SO}\right)^{-}$and TS relative energies- $\mathrm{La}$ in red, $\mathrm{Yb}$ in blue and $\mathrm{Lu}$ in green - with respect to the $\mathrm{Ln}\left(\mathrm{CH}_{3} \mathrm{SO}_{2}\right)_{4}{ }^{-}$initial complex. 


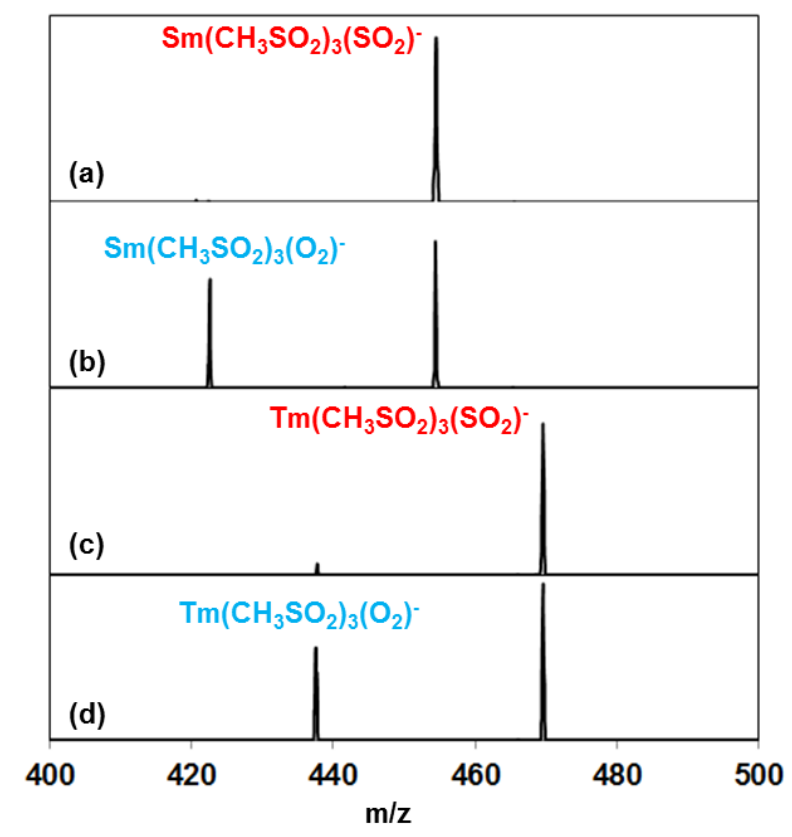

Figure 6. Mass spectra of isolated $\mathrm{Sm}\left(\mathrm{CH}_{3} \mathrm{SO}_{2}\right)_{3}\left(\mathrm{SO}_{2}\right)^{-}$(a) and $\operatorname{Tm}\left(\mathrm{CH}_{3} \mathrm{SO}_{2}\right)_{3}\left(\mathrm{SO}_{2}\right)^{-}$(c). Spectra (b) and (d) were obtained after reactions of $\mathrm{Sm}\left(\mathrm{CH}_{3} \mathrm{SO}_{2}\right)_{3}\left(\mathrm{SO}_{2}\right)^{-}$and $\mathrm{Tm}\left(\mathrm{CH}_{3} \mathrm{SO}_{2}\right)_{3}\left(\mathrm{SO}_{2}\right)^{-}$with background $\mathrm{O}_{2}$ in the ion trap for $0.3 \mathrm{~s}$. 


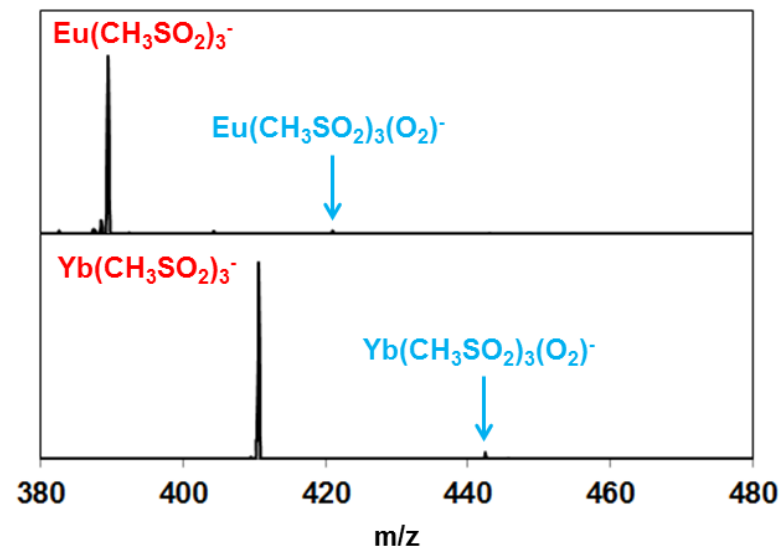

Figure 7. Mass spectra obtained after reactions of isolated $\mathrm{Eu}\left(\mathrm{CH}_{3} \mathrm{SO}_{2}\right)_{3}{ }^{-}$and $\mathrm{Yb}\left(\mathrm{CH}_{3} \mathrm{SO}_{2}\right)_{3}{ }^{-}$with background $\mathrm{O}_{2}$ in the ion trap for $0.5 \mathrm{~s}$. 